\title{
Are bank loans to SMEs procyclical? Evidence from an analysis of the lending behavior of Korean banks
}

\author{
Ji-Yong Seo \\ Department of Business Administration, Sangmyung University, \\ 7 Hongji-dong, Jongno-gu, Seoul 110-743, Korea \\ jyseo@smu.ac.kr
}

\begin{abstract}
This paper investigates the procyclicality of bank loans to Small and Medium Enterprises (SMEs) and to Large Enterprises (LEs) using aggregated and cross-sectional data from major private, foreign, and state-owned banks in Korea in the period from 1999 to 2008. Based on previous studies, it is hypothesized that compared to LEs, banks loans to SMEs may be more vulnerable to external economic shock. Berger and Udell (1994) suggested that bank loans to SMEs are comparatively risky due to their relatively low collateral and heavy dependence on banks for raising funds. In this study, empirical tests are verified by applying the rolling vector error correction Model (VECM), panel generalized least squares model (GLS), and the Clustering Fixed Effect Model. Findings include robust support for the procyclicality of bank loan to SMEs, but not for LEs. The review of short-term dynamics among first differential variables such as loans and GDP provides evidence to support a related hypotheses: the profit-oriented motivation of commercial banks in enhancing relationships with SMEs, the characteristics of governance structure in three types of banks (private, state-owned, and foreign owned banks), and the large-bank barriers assumption.
\end{abstract}

*To whom all correspondence should be addressed.

\section{Introduction}

Global financial difficulties caused by the sub-prime mortgage crisis in the latter half of 2008 triggered the current global economic recession. Many financial institutions that had invested in derivatives linked to subprime mortgages faced insolvency, and the international credit crunch and fluctuating exchange rates resulted in a drastic reduction in both consumption and investment. The Korean economy, which is heavily dependent on export, has faced serious difficulties due to the worsening domestic market conditions experienced by its major trading partners, including the U.S. However, the global economic recession has also had a direct effect on Korean companies and financial institutions.

It is assumed that during a recession, small and medium Enterprises (SMEs) are more likely to suffer a lack of funds and reduced achievements compared to Large Enterprises (LEs). As large companies reduce production, SMEs are expected to receive fewer orders, resulting in decreased sales and decreased profits. It is also expected that financial institutions will reduce loans to SMEs in order to counter rising insolvencies, and therefore, even some profit-making SMEs are expected to become bankrupt. Furthermore, in the wake of the introduction of the new Basel Accord (2008), in which weighted risk is applied according to borrowers' credit rating, financial institutions are expected to reduce drastically loans to SMEs. Since SMEs do not have sufficient collateral relative to LEs, financial institutions such as commercial banks are expected to collect loans and refrain from extending new ones. Thus, it is expected that
SMEs, which are heavily dependent on loans extended by financial institutions, will face increasingly difficult managerial challenges due to a lack of funds.

Commercial banks in Korea have had difficulties in managing assets because of reduced profit margins and intensified competition among banks, which have drastically increased loans to SMEs in an effort to expand business. In the first half of 2005, the net amount of loans extended to SMEs increased by only 3,0 trillion won (about USD 2,5 billon) from the year before. In the first half of 2006, the amount increased by 19 trillion won (about USD 15,8 billon) and in the first half of 2008, by 68 trillion won (about USD 56,5 billon). However, since early 2009, the net amount of these loans has been gradually decreasing. In the beginning of 2010, the net increase was only 14 trillion won (about USD 11,4 billion). The global economic recession caused by financial crises in the U.S. has resulted in the reduction of the fund raising capacity of SMEs. This implies that bank loans to SMEs seem to have responded to the volatility in business fluctuation before the global economic crisis. Thus, it seems to indicate that there has been fundamental change in the SMEs loan market in Korea. However, it also seems that the capital adequacy ratios of Korean commercial banks are still good judging by the average of Bank for International Settlement (BIS) ratio of $11,27 \%$. In recent years, financial authorities have asked the banking sector to finance SMEs proactively in an effort to help them resolve their lack of funds. The authorities promoted this action by demonstrating their intention to operate flexibly the standard of financial soundness for banks. Specifically, they reduced the BIS ratio to as low as 
$10 \%$, but the banks still felt that extending loans to SMEs would be a burden.

In the light of the fluctuations in SMEs financing, the relationship between economic conditions and bank loans to SMEs has emerged as an important issue in the financial sector of Korea. This paper aims to examine whether a comovement between business cycles and bank loans exists through an empirical analysis of quarterly aggregated data and panel data on Korea. In other words, the objective of this paper is to explain the relationship between the lending behaviors of banks to SMEs or LEs and business cycle, which is called the hypothesis of procyclicality. It argues that bank loans are affected over business cycles. It insists that the lending behavior of banks toward enterprises, especially SMEs, differs during times of economic boom and recession, and holds that loans increase during economic expansion and decrease during economic recession. If procyclical of bank loans exists, it is expected to affect struggling Korean SMEs negatively. Thus, this result could contribute to urging the financial authorities to take steps to alleviate the procyclicality. This result would also contribute to the literature on financial institutions and shed light on the theme of SME-related financing.

In order to verify research question, the study is conducted in the following order. In Chapters 2 and 3, related studies are reviewed and appropriate hypotheses are suggested. In Chapter 4, the data and verification models used in the study are examined. In Chapter 5, the results of the analyses and their interpretations are discussed. Finally, the summary and conclusion are presented in Chapter 6.

\section{Related literature}

Prior to the examination of the existing literature, detailed study of the subject of this research is needed. The study analyses the lending behavior of commercial banks during changes in business cycles. Lending behavior is examined for key factors affecting loans to enterprises, such as aggregated economic variables and bank characteristics. The method of analysis is classified into two parts. As the first part, a dynamic methodology is adopted to determine the relationship between bank loans made on an aggregated basis and real GDP variables as a proxy for business cycles or economic fluctuation. In this step, in order to confirm the effect of lending behavior over changes in business cycles, effects on lending behavior during changes in business cycles are reviewed. These effects are examined dynamically in accordance with the flow of time. The effect means the relationship of balance between the first differentials of the bank loan as a dependent variable and the business cycle level as an explanatory variable if cointegration vectors among variables in time series statistically exist. The test also catches dynamic relationships among first differential variables.

The second part tests panel data to resolve some biases ${ }^{1}$ in the time series data on an aggregated basis. Analysis of the

1 Baltagi (1996) suggested that the efficiency of estimation of parameters through panel data analysis could be improved by controlling the heterogeneity of each variable. cross-sectional bank loan data of three types of banks private, state-owned, and foreign-owned - and other bank characteristics, will re-confirm the procyclicality of bank loans to SMEs, the dynamic relationships among first $1^{\text {st }}$ differential variables, and verify other banking hypotheses, such as the governance structure issue and large-bank barriers.

With regard to the topic of the study, the procyclicality hypothesis is examined in the light of mainly academic interest. Let us review the previous research on the procyclicality issue.

Ayuso, Perez and Saurina (2004) analyzed the relationship between Spanish business cycles and capital buffers, which he defined as the bank's capital less the requirements divided by the requirements that cover the period 19862000 comprising a complete cycle. Instead, this research considers the capital buffers on assumption that an increase in loans implies an increase in capital requirements. The study concluded that rising credit risks caused by increasing loans led to increased capital requirements, eventually reducing surplus capital. It argued that bank loans have procyclicality, and relatively risky loans to SMEs go through drastic reductions in surplus capital during economic expansion, so they have stronger pro-cyclicality than loans to LEs.

Ayuso et al. (2004) found a negative relationship between capital buffers and business cycles. This finding supports the view that banks may behave in an excessively lax manner in managing capital buffers during economic upturns, and vice versa. As evidence supporting procyclicality, the study found that surplus capital reduced by $17 \%$ whenever the economy increases by $1 \%$.

Jokipii and Milne (2008) analyzed banks in 15 EU countries in order to determine procyclicality of capital buffers of banks similar to bank loans. Using an unbalanced panel of accounting data from 1997 to 2004, their study showed that capital buffers of banks in the EU 15 have a significant negative co-movement with business cycles. The study insisted that capital buffers of commercial and saving $\mathrm{s}$ banks, especially large financial institutions, exhibit negative co-movement and interpreted that negative comovement of capital buffers means the impact of procyclicality.

Estrella (2004), Lindquist (2004), and Micco and Panizza (2006) analyzed the lending behavior of banks according to business cycle to explain the procyclicality of banks.

Peek and Rosengren (1995) and Gambacorta and Mistrulli (2004) argued that low-capitalized banks are forced to cut their loan supply during a recession. Thus, they suggested that the banks having weak capital adequacy are procyclical to business cycle fluctuation. Benford and Nier (2007) supported Gambacorta and Mistrulli (2004). However, Nier and Zicchino (2005), Benford and Nier (2007), and Francis and Osborne (2009) asserted that banks tend to cut lending when the capital adequacy ratio falls below desirable levels. 
However, there have been some interesting researches on the relationship between procyclicality and bank regulations under Basel Accord II. Kashyap and Stein (2004) and Saurina and Tucharte (2006) reported that bank regulations may amplify procyclicality inherent in the lending behavior of banks. Because it aims at making minimum capital requirements, lending behavior of banks is more sensitive to the underlying risk of banks' operations than the formal framework set out in Basel Accord I. In the light of previous studies, it is assumed that Korean banks may have the possibility of procyclicality in loans to SMEs loan under Base Accord II, which sets out the current capital regulation framework.

This study analyzed mainly whether state ownership of banks is correlated with lending behavior over business cycles, finding that their lending behavior is less responsive to macroeconomic shocks than that of private banks(domestic and foreign-owned). It is implied that stateowned banks could play a useful role in the transmission of financial policy. However, the study also showed the interesting finding that the lending of public banks located in developing countries seems less procyclical than the lending of public banks located in industrial countries.

Previous research also focused how monetary policies affect bank loans instead of business cycles. The strong relationships between business cycles and monetary policies need to be understood in the context of the analysis of relationships between business cycles and lending behavior. According to Bernanke and Blinder (1988), an excessive economic expansion results in tight monetary policy by the financial authorities. During tight monetary expansion, SMEs having difficulty accessing the capital market may face difficulties in obtaining financing from banks. In other words, changes in monetary policy lead to changes in the capacity of banks to provide loans. Moreover, business cycles have a relatively greater effect on SMEs than banks do in terms of fund raising.

Regarding monetary policy, Kashyap and Stein (2000), Kishan and Opiela (2006) focused on the difficulties in distinguishing shifts in bank loan demand from shifts in loan supply. These shifts prompted the researchers to focus on panel data to test for the existence of a loan supply function. They looked at the importance of bank characteristics for individual bank lending following a monetary policy change. They insisted that smaller and least capitalized banks are the most responsive to a monetary policy change.

Another requirement is study of how bank characteristics, such as standards of capital adequacy, loan soundness, and profitability, affect lending behavior. In other words, the research theme concerns whether the managerial conditions of banks have a great effect on loans to enterprises. There have been many empirical studies on how the managerial conditions of banks affect loans to SMEs. Chiou (1999), Claessens, Djankov and Ferri (1999), Djankov, Jindra and Klapper (2000), Kang and Stulz (2000) and Ongena, Smith and Michalsen (2000) found that banks vulnerable to capital adequacy had negative effects on corporate fund raising.
In particular, Berger and Udell (1994), Peek and Rosengren (1995), Hancock, Laing and Wilcox (1995), Shrieves and Dahl (1995), and Wagster (1999) thought a low BIS ratio of banks as proxy of capital adequacy has made government supervisors strengthen regulations, which results in a negative impact on loan to SMEs.

These studies examined the issue that interested parties such as government supervisors, depositors, investors, and riskaverse managers of banks may affect lending behavior caused by bank characteristics.

However, Berger et al. (2001) argued that the characteristics of Argentinean banks, such as standards of loan soundness, had nothing to do with loans to SMEs relative to LEs. This study analyzed the relationship between the managerial conditions of banks and changes in loan to SMEs by using data on proxy variables related to capital adequacy, loanextension soundness, and profitability. However, noting that bank ownership affects lending behavior regarding SMEs, the study insists that large and foreign-owned banks may have difficulty extending relationship loans to opaque small firms.

Previous research also refutes the co-movement between bank loans and business cycles. In a typical study, Dell'Ariccia and Marquez (2001) observed that some banks enhanced relationships with SMEs, tending to increase loans to them in order to generate future profits despite economic recessions.

\section{Hypotheses and the variables that affect bank loans}

To analyze the procyclicality issue, the present study proposes hypotheses that based on the previous research discussed above. The first hypothesis aims to verify procyclicality of bank loans to SMEs and LEs under standard controlling bank characteristics such as the Bank for International Settlement (BIS) ratio, the amount of the Allowance for Bad Debts (ABD), and the level of the Net Interest Margin (NIM). It aims to control for the fact that the managerial conditions of banks may have a great effect on lending behavior. It is hypothesized that bank loans to SMEs are determined by changes in the business cycle under controlling bank characteristics, such as proxy variables representing the degree of capital adequacy, soundness, and profitability.

Based on Micco and Panizza's study (2006), the second hypothesis states that state-owned banks are less responsive to shocks in the business cycle because of the characteristics of government structures. It is considered that state-owned banks tend to increase or decrease promptly bank loans over changes in business cycles because of the role of financial policy in credit stabilization.

Third hypothesis is as follows. Smaller and least capitalized banks are the most responsive to changes in the business cycle regarding large bank barriers (Kashyap \& Stein, 2000; Kishan \& Opiela, 2006). This assumption is based on the idea that smaller banks that lack a capital buffer tend to be affected by interested parties and make lending behavior 
changes in response to changes in economic conditions. Thus, the third hypothesis examines whether changes in bank loan divided into SMEs loans and LEs loans are significantly influenced by business cycles in proportion to economic conditions.

These hypotheses are first verified using the rolling Vector Error Correction (VECM) model consisting of aggregated variables because of the need to resolve biases in the sample selection bias $^{2}$. Furthermore, they are also empirically tested using panel data analysis in order to check the results of analysis of aggregated variables. Let us now review the variables used in this study.

\section{GDP: (+ or - in case of first differentials and + in case of level variables)}

It is assumed that lending behavior is related to the business cycle. Domestic GDP growth is used as a proxy variable (Jokipii \& Milne, 2008). The reason that bank loans to enterprises respond to macroeconomic shocks is that bank failures are more likely during recessions. Thus, the banks are reluctant to increase lending or they may reduce the amount of loans to companies. However, the relationship between GDP and first differentials of bank loans might differ according to the type of bank ownership and the size of the borrower, despite the instability of the relationship between the economic growth rate and first differentials of bank loans. ${ }^{3}$ To investigate procyclicality between bank loans and GDP, it is desirable for us to isolate the relationship between GDP and the change in loans. As the literature review indicated, it is expected that GDP comoves with the trend in bank loans.

However, with regard to the dynamics of the relationship between business cycles and type of bank ownership, it is assumed that the lending behavior of state-owned banks is relatively less responsive to economic conditions (Micco \& Panizza, 2006). That is, the lending behavior of state-owned banks is less responsive to macroeconomic shocks than that of non-public banks because credit stabilization is their main role and objective function. Therefore, the first differential variable associated with bank loans in state-owned banks is less responsive to changes in the business cycle than that of private or foreign-owned banks. Furthermore, it is expected that lending behavior of foreign-owned banks in relation to the business cycle might differ from that of domestic banks.

With regard to the type of borrower, it is expected that lending behavior is different to SMEs or LEs in relation to the business cycle. Hence, commercial or private banks are less likely to lend to informationally opaque SMEs than to LEs that have the public's confidence. Specifically it is

\footnotetext{
${ }^{2}$ Guirguis et al. (2005) employed the rolling VECM technique, which does not affect the sample period selection bias as well as examining th e dynamic relationship among aggregated economic and financial varia bles.

${ }^{3}$ In a short-term period, bank loans to companies tend to increase or de crease regardless of the business cycle. Aggregate bank loans may incr ease or decrease during recession or expansion due to the active market ing strategy of commercial banks to establish relationship (Dell'Ariccia \& Marquez, 2001) lending or precautionary steps as risk management.
}

found that foreign-owned banks or organizations tend to lend to the large corporate affiliates of their customers (Grosse \& Goldberg, 1991). Therefore, in the light of procyclicality, which analyzes the relationship between GDP and the change of bank loans, it is assumed that bank loans to SMEs correspond more to the business cycle than bank loans made to LEs.

\section{Control variables}

Prior studies showed that control variables, such as typical bank characteristics representing capital regulatory ratio (CRR). The proxies for risk are allowance for bad debts (ABD) and the non-performing loans (NPL) to total loans (TL) ratio. The cost of holding such a surplus or profitability like return on equity (ROE) or net interest margin (NIM) need to be included in empirical models verifying the relationship between bank loans and the business cycle (Jokipii \& Milne, 2008).

Previous studies have indicated why these variables should be used when confirming procyclicality.

Ayuso et al. (2004) argue that a negative relationship exists between the capital buffers of banks and GDP growth rate. Therefore, they must be controlled in an estimated model.

As a proxy variable for the measurement of risk, Ayuso et al. (2004) used the NPL ratio to estimate the relationship between the Spanish business cycle and the capital buffers held by commercial and savings banks. Aggarwal and Jacques (2001) also adopted the NPL ratio as a proxy variable representing financial soundness. They reported that change in the NPL ratio may affect lending behavior, cutting the supply of credit. Albertazzi and Gambacorta (2009) used provisions or allowance for bad debts as a component that affects the business cycle. Various authors have shown that ABD and GDP are negatively correlated (Salas \& Saurina, 2002; Laeven \& Majoni, 2003). In particular, Beatty and Liao (2011) adopted ABD as a proxy variable representing financial soundness and suggested that this variable may affect the lending behavior of banks. They reported that forward-looking provisioning mitigates procyclicality in lending. Furthermore, Barth, Caprio and Levine (2006) adopted bank regulatory variables such capital adequacy ratio to isolate economic consequences of discretion in loan loss provisioning affect the lending behavior of banks.

Furthermore, it is considered that NIM is related to longterm interest rates because the latter are closely related to GDP growth rates. In Albertazzi and Gambacorta (2009), the nominal value of the net interest margin is expected to increase by almost $4 \%$ in the long run if the long-term interest rate rises by 1 percentage point. In addition, Milne and Whalley (2001) argued that the lending behavior of banks can be affected by banks' profitability levels because banks with high profitability have a sufficient financial buffer to meet the minimum capital requirement resulting in an increasing supply of credit. Stolz and Wedow (2011) also reported that banks' profitability may affect the lending behavior of banks via changing the level of capital buffer in the banks. 
To investigate the procyclicality of bank loans to SMEs and LEs, in terms of the relationship between GDP and the change of loans, aggregated data and proxy variables representing typical bank characteristics as control variables were used. In this paper, three control variables that may affect the lending behavior of banks are adopted in the empirical test model. BIS ratio as capital adequacy or capital regulation level, $\mathrm{ABD}$ as financial soundness, and NIM as profitability, which are generally used in banking studies.

\section{Data and sample statistics}

\section{Data}

The following data is used in the study. First, real GDP are used as an economic indicator. Bank loans to SMEs and LEs are used. Regarding amounts of loans to SMEs and LEs, the average remainder of loans to companies was used. To control for the managerial conditions of banks, such as capital adequacy, soundness of loan, and profitability in aggregated analysis using Rolling VECM, we use the BIS ratio, $\mathrm{ABD}$, and NIM as the proxy variables.

Regarding the panel data analysis, bank loans to SMEs and LEs including the lagged BIS ratio, NPL ratio, and NIM of nine banks (four major private banks, three foreign banks, and two state-owned banks) in Korea were used to check whether bank characteristics affect lending behavior.

The period analyzed is fourth quarter of 1999 to fourth quarter of 2008. Data was obtained from Fnguide.com, Financial Statistics Information System in Financial Supervisory Service and statistical information in the Korea $\mathrm{n}$ Institute of Finance.

\section{Variables and summary statistics}

Table 1 presents the definition of variables used in the sample. Among the key variables, the dependent variables used in this paper are applied in two ways: 1) as aggregated analysis using rolling VECM; and 2) as panel data analysis.

Table 1: Definition of the variables

\begin{tabular}{|c|c|c|}
\hline Analysis way & Variables & Definitions \\
\hline \multirow[t]{7}{*}{ The aggregated analysis } & GDP as a level (lnGDP) & $\begin{array}{l}\text { Real Gross Domestic Product quarterly basis standardized } \\
\text { using natural logarithmic scale }\end{array}$ \\
\hline & $\Delta \mathrm{GDP}$ & $\ln G D P(t)-\ln G D P(t-1)$ \\
\hline & 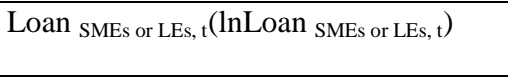 & $\begin{array}{l}\text { The amounts of bank loans to SMEs or LEs standardized } \\
\text { using natural logarithmic scale }\end{array}$ \\
\hline & $\Delta$ Loan ${ }_{\text {SMEs or LEs, } t}$ & $\ln \operatorname{Loan}(\mathrm{t})-\ln \operatorname{Loan}(\mathrm{t}-1)$ \\
\hline & BIS capital ratio (BIS) & Capital to risk-weighted asset $\times 100$ \\
\hline & Allowance for Bad Debts(ABD) & $\begin{array}{l}\text { Allowance for Bad Debts on quarterly basis standardized } \\
\text { using natural logarithmic scale }\end{array}$ \\
\hline & Net Interest Margin (NIM) & $\begin{array}{l}\text { Net interest margin is a measure of the difference between the } \\
\text { interest income generated by banks and the amount of interest } \\
\text { paid out to their lenders, relative to the amount of their } \\
\text { interest-earning assets }\end{array}$ \\
\hline \multirow[t]{8}{*}{ The panel data analysis } & Co-integration Vector(CIV. SMEs or LEs, $\mathrm{t}$ ) & $\begin{array}{l}\text { Co-integration vector between each bank loans to SMEs or } \\
\text { LEs and GDP }\end{array}$ \\
\hline & Bank Ownership Dummy1 $\left(\mathrm{BO}_{1}\right)$ & $\begin{array}{l}\text { Managerial ownership of banks is equal to }-1 \text { or } 1 \text { if the banks } \\
\text { are State owned or private. } \\
\text { It is a proxy for banks' ownership constraints }\end{array}$ \\
\hline & Bank Ownership Dummy2($\left(\mathrm{BO}_{2}\right)$ & $\begin{array}{l}\text { Managerial ownership of banks is equal to }-1 \text { or } 1 \text { if the banks } \\
\text { are foreign or domestic. } \\
\text { It is a proxy for banks' ownership constraints }\end{array}$ \\
\hline & Bank size Dummy(ln size) & Bank's asset size $=\ln ($ asset $)$ \\
\hline & $\Delta$ Loan $_{\text {SMEs, }}$ t or LEs, $\mathrm{t}$ & $\begin{array}{l}\text { The rate of state-owned banks' loans to SMEs or Les } \\
\text { standardized using natural logarithmic scale for panel data } \\
\text { analysis }\end{array}$ \\
\hline & BIS ratio of each bank $\left(B I S_{i, t}\right)$ & Capital to risk-weighted asset $\times 100$ in each bank \\
\hline & NPL ratio of each bank $\left(\mathrm{NPL}_{\mathrm{i}, \mathrm{t}}\right)$ & Non Performing Loans / Total loans $\times 100$ in each bank \\
\hline & NIM of each bank(NIM $\left.{ }_{i, t}\right)$ & $\begin{array}{l}\text { The difference between the interest income generated by each } \\
\text { bank and the amount of interest paid out to their lenders, } \\
\text { relative to the amount of their interest-earning assets }\end{array}$ \\
\hline
\end{tabular}

\footnotetext{
Note: ( ) indicates the sign used in estimated model.
} 
Table 2 reports the summary statistics for the main variables of SMEs and LEs used in this study. Real GDP is about 208 trillion won (about USD 173 billion) on average, and up to 256 trillion won (about USD 213 billion) were recorded during the analysis period. In addition, the average loans to SMEs and LEs as the aggregated variables is approximately 238 trillion won (about USD 198 billion) and 36 trillion won (about USD 30 billion) respectively. In addition, regarding the control variables, the BIS ratio, $\mathrm{ABD}$, and NIM are $11,3 \%, 12$ trillion won (about USD 10 billion) and about 2,6\% to SMEs and LEs, respectively. All variables except for real GDP in the aggregated variables are distributed positively according to the degree of skewness. The degree of skewness of real GDP is $-0,06$.

Regarding the statistics of the cross-sectional data, the sized of private bank loans among the three categorizes of banks is bigger than any other type of bank. Moreover, the BIS ratio is better in state-owned banks $(13,77 \%)$ than private banks $(12,88 \%)$ and foreign banks $(12,68 \%)$. In the case of NPL, foreign banks $(1,04 \%)$ are the best followed by private banks $(1,06 \%)$ and state-owned banks $(1,20 \%)$. These results are consistent with the previous study by Berger et al. (2005), which found that state-owned institutions have relatively high numbers of nonperforming loans. Moreover, the foreign banks' average NIM of 2,66 is much higher than that of private and the state-owned banks. Hence, foreignowned banks have a much bigger cost of holding a surplus and are better positioned to make a profit.

Table 3 shows the basic test of difference in means for main variables used in this analysis to compare LEs and SMEs. In the mean difference test between LEs and SMEs, all variables are different and statistically based on the t-test and Van der Waerden test ${ }^{4}$ except the NPL ratio. Thus it is understood that the variables for SMEs are distinct from those of LEs.

\section{Empirical test results}

In this section, results for the rolling VECM and panel data analysis are presented. As mentioned earlier, the rolling VECM is used to verify the existence of procyclicality by identifying the relationship between GDP and the first differentials of bank loans to SMEs and LEs. A panel GLS and Clustering Fixed Effect Model are then used to confirm the existence of the relationship between GDP and the change in bank loans.

\section{The rolling VECM and results}

The rolling VECM suggested above is as follows:

$$
\begin{aligned}
& \Delta \operatorname{Loan}_{\mathrm{LEs}(\text { orSMEs }), \mathrm{t}}=\alpha_{0}\left(\ln \operatorname{Loan}_{\mathrm{LEs}(\text { orSMEs }), \mathrm{t}-1}+\beta_{0} \ln \mathrm{GDP}_{\mathrm{t}-1}\right. \\
& \left.+\beta_{1} @ \operatorname{trend}_{\mathrm{t}}+\gamma\right)+\beta_{2} \Delta \operatorname{Loan}_{\mathrm{LEs}(\operatorname{orSMEs}), \mathrm{t}-1} \\
& +\beta_{3} \Delta \mathrm{GDP}_{\mathrm{t}-1}+\delta+\beta_{4} \operatorname{Control}\left(\mathrm{BIS}_{\mathrm{t}}\right)+\beta_{5} \operatorname{Control}\left(\mathrm{ABD}_{\mathrm{t}}\right) \\
& +\beta_{6} \operatorname{Control}\left(\mathrm{NIM}_{\mathrm{t}}\right)
\end{aligned}
$$

\footnotetext{
${ }^{4}$ This test is based on the same general idea as the Wilcoxon test, but it uses smoothed ranks. The signed ranks are smoothed by converting them to quantiles of the normal distribution.
}

where

each window period ${ }^{5}$ for analysis is applied to $t$ 16 quarters $\sim \mathrm{t}+16$ quarters. In this model, control variables include the BIS ratio, ABD, and NIM. @trend and $\gamma$ are time trend and intercept respectively within the cointegration vector in parenthesis. $\delta$ indicates intercept in whole model. In Table 6 and Table 7, (1) (6) means that each window period increased by 1 -quarter from $1999.4 \mathrm{q}$ $\sim 2007.3 q$ to $2001.1 q \sim 2008.4 q$.

This model is designed for the verification of the procyclicality hypothesis under controlling bank characteristics. The Rolling VECM was used to verify the hypothesis that loans to SMEs and LEs are determined by changes in the business cycle under the controlling standards of capital adequacy ratio, ABD as buffer of credit risks, and NIM as the pivotal variable for profit-making conditions. Regarding the method of analysis method, this model means that VECM based on loan to SMEs or LEs and GDP was consecutively applied to each data set by increasing 1-quarter from $\mathrm{t}$-16quarters to $\mathrm{t}+16$ quarters in order to acquire estimated coefficients. In addition, this model shows the short-term dynamics between change of bank loan and lagged change of GDP growth rate. Namely, it aims to confirm relationships among pertinent variables of level and first difference as time progressed.

The model $\left(\ln L o a n_{\mathrm{LEs}(\text { orSMEs }), t-1}+\beta_{0} \ln _{\mathrm{GDP}_{\mathrm{t}-1}}+\beta_{1} @ \operatorname{trend}_{\mathrm{t}}+\gamma\right)$ is a co-integration vector between a level variable of bank loan to SMEs (or LEs) and GDP, including the time trend and intercept. In this model, the co-integration vector will affect to the change rate of bank loan (the first differential of bank loan) to adjust to the equilibrium if the balance between loan and GDP is collapsed.

Therefore, the existence of procyclicality between the first differentials of bank loan and GDP is determined by the signs $\alpha_{0}$ and $\beta_{0}$. If procyclicality exists in the bank loan, $\beta_{0}$ is expected to be a significantly positive sign. Furthermore, $\alpha_{0}$ shows as a negative sign with significance if $\beta_{0}$ is expected to be a significantly negative sign due to the unbalanced relationship among the first differentials. In other words, a negative sign of coefficient of adjustment to equilibrium with significance implies that $\beta_{0}$ changed to a positive sign.

In addition, this model also shows the dynamic relationship between the change rate of the loan and independent variables of the first differentials.

The model $\Delta \operatorname{Loan}_{\mathrm{LEs}(\text { orSMEs }), \mathrm{t}}, \Delta \operatorname{Loan}_{\mathrm{LEs}(\text { orSMEs }), t-1}$ and $\Delta \mathrm{GDP}_{\mathrm{t}-1}$ of first differential variables shows the dynamics between business cycle and loan growth rate. However, the relationship may be adjusted by the co-integration vector shown above. This implies that $\alpha_{0}$, the adjustment coefficient, is statistically significant.

\footnotetext{
${ }^{5}$ The determination of the window period for dynamic analysis of VECM is attributed to the period of business cycle published by the Bank of Korea. It is analyzed in the data for each window period before 16-quarter and after 16-quarter as of this time 1-cycle period which is a four-year average in the 2000s.
} 
Table 2: Summary statistic

\begin{tabular}{|c|c|c|c|c|c|c|c|}
\hline & Variables & Mean & $\begin{array}{l}\text { Std. } \\
\text { Dev }\end{array}$ & $\begin{array}{l}\text { Degree of } \\
\text { skewness }\end{array}$ & Kurtosis & $\begin{array}{c}\text { The } \\
\text { maximum } \\
\text { value }\end{array}$ & $\begin{array}{c}\text { The } \\
\text { minimum } \\
\text { value } \\
\end{array}$ \\
\hline \multirow{5}{*}{$\begin{array}{l}\text { The aggregated } \\
\text { variables }\end{array}$} & Real GDP(trillion won) & 207,53 & 27,16 & $-0,06$ & 2,13 & 256,00 & 150,27 \\
\hline & $\begin{array}{l}\text { Loans to SMEs(based on average } \\
\text { remainder, trillion won) }\end{array}$ & 238,46 & 79,71 & 0,54 & 2,36 & 400,32 & 131,22 \\
\hline & $\begin{array}{l}\text { Loans to Les(based on average } \\
\text { remainder, trillion won) }\end{array}$ & 35,74 & 92,03 & 0,99 & 3,08 & 594,30 & 246,48 \\
\hline & BIS ratio $(\%)$ & 11,27 & 0,88 & 0,56 & 1,80 & 12,78 & 9,95 \\
\hline & $\begin{array}{l}\text { Allowance for Bad Debts(trillion } \\
\text { won) }\end{array}$ & 12,00 & 3,70 & 1,17 & 3,20 & 21,42 & 8,24 \\
\hline \multirow{15}{*}{$\begin{array}{l}\text { The variables of } \\
\text { cross-sectional } \\
\text { data }\end{array}$} & $\ln$ (Loans to LEs by Private Banks) & 17,12 & 0,37 & $-0,30$ & 1,36 & 17,54 & 16,58 \\
\hline & $\begin{array}{l}\ln \text { (Loans to LEs by State-owned } \\
\text { Banks) }\end{array}$ & 16,67 & 0,30 & $-0,10$ & 1,39 & 17,03 & 16,28 \\
\hline & ln Loans to LEs by Foreign Banks & 15,75 & 0,31 & $-0,07$ & 1,34 & 16,12 & 15,30 \\
\hline & $\begin{array}{l}\text { ln (Loans to SMEs by Private } \\
\text { Banks) }\end{array}$ & 18,98 & 0,19 & $-0,66$ & 1,95 & 19,16 & 18,63 \\
\hline & $\begin{array}{l}\text { ln (Loans to SMEs by State-owned } \\
\text { Banks) }\end{array}$ & 18,19 & 0,18 & $-0,09$ & 1,76 & 18,43 & 17,90 \\
\hline & $\begin{array}{l}\text { ln (Loans to SMEs by Foreign } \\
\text { Banks) }\end{array}$ & 17,27 & 0,11 & $-0,76$ & 2,34 & 17,41 & 17,06 \\
\hline & BIS of Private Banks (\%) & 12,88 & 1,33 & 0,25 & 2,21 & 15,27 & 10,74 \\
\hline & BIS of State-owned Banks (\%) & 13,77 & 0,89 & $-0,46$ & 1,76 & 14,94 & 12,22 \\
\hline & BIS of Foreign Banks (\%) & 12,68 & 1,53 & 0,22 & 2,23 & 15,33 & 10,34 \\
\hline & NPL of Private Banks (\%) & 1,06 & 0,33 & 0,70 & 2,00 & 1,61 & 0,72 \\
\hline & NPL of State-owned Banks (\%) & 1,20 & 0,40 & 1,37 & 4,63 & 2,31 & 0,77 \\
\hline & NPL of Foreign Banks (\%) & 1,04 & 0,25 & 0,57 & 2,12 & 1,50 & 0,74 \\
\hline & NIM of Private Banks (\%) & 2,39 & 0,33 & $-0,62$ & 1,98 & 2,78 & 1,82 \\
\hline & NIM of State-owned Banks (\%) & 1,51 & 0,21 & 2,10 & 7,65 & 2,18 & 1,34 \\
\hline & NIM of Foreign Banks (\%) & 2,66 & 0,22 & $-0,36$ & 2,42 & 3,02 & 2,27 \\
\hline
\end{tabular}

Table 3: Mean different test of variables between LEs and SMEs

\begin{tabular}{|c|c|c|c|c|c|c|c|}
\hline \multirow{2}{*}{$\frac{\text { Variables }}{\text { Loans to LEs }}$} & \multirow{2}{*}{$\begin{array}{c}\text { Major private } \\
\text { Bank }\end{array}$} & \multirow{2}{*}{$\begin{array}{c}\begin{array}{c}\text { State owned } \\
\text { Bank }\end{array} \\
16,67\end{array}$} & \multirow{2}{*}{$\begin{array}{c}\begin{array}{c}\text { Foreign } \\
\text { owned Bank }\end{array} \\
15,75\end{array}$} & \multicolumn{2}{|c|}{ t-Test } & \multicolumn{2}{|c|}{$\begin{array}{c}\text { Van der Waerden } \\
\text { Test }\end{array}$} \\
\hline & & & & 72,31 & $* * *$ & 33,17 & $* * *$ \\
\hline Loans to SMEs & 18,98 & 18,19 & 17,27 & 454,02 & $* * *$ & 38,62 & $* * *$ \\
\hline BIS ratio (\%) & 12,88 & 13,77 & 12,68 & 3,35 & $* *$ & 4,44 & $*$ \\
\hline NPL ratio $(\%)$ & 1,06 & 1,20 & 1,04 & 1,11 & & 2,14 & \\
\hline NIM (\%) & 2,39 & $\mathbf{1 , 5 1}$ & 2,66 & 86,00 & $* * *$ & 31,06 & $* * *$ \\
\hline
\end{tabular}

Note: $* * *, * *$, and $*$ denote significant $1 \%, 5 \%$, and $10 \%$ respectively

In this dynamic model, the coefficients related to the cointegration vector are $\beta_{0}, \beta_{1}$, and $\gamma$, and the coefficients of $\beta_{2} \sim \beta_{6}$ indicate the dynamics.

Pre-test on time series variables: unit root, cointegration tests etc.

It is verified whether time series variables, such as GDP and bank loans, are non-stationary in an autoregressive model. The well-known augmented Dickey-Fuller (ADF) test is used here. The null hypothesis is that a unit root exists in these variables. The unit root test should be conducted first to determine whether the individual series are non-stationary in the levels, and whether they are stationary in the differentials.

Table 4 presents the results from the ADF and PhillipsPerron tests, which show that all three variables are non- stationary in levels because the null hypothesis is not rejected. The test was then conducted again for the differentials, and the results show that all individual series are stationary, thus rejecting the null hypothesis at minimum $5 \%$ significance level of $5 \%$.

The test also adopts one, the number of the lagged level terms, as an optimal lag chosen by minimizing the Schwarz Bayesian criteria (SBC).

Table 5 shows the results from the co-integration test, which are based on the Johansen test. A system of two or more time series that are non-stationary in levels can share common stochastic trends that are co-integrated. If a linear combination of these variables is stationary, the nonstationary time series is cointegrated, and it is interpreted as long-run equilibrium relationships among GDP and bank loans. According to Table 5, cointegration between GDPs 
and bank loans is evident. A single co-integration relation exists for GDP and bank loans to SMEs (or bank loans to LEs). In co-integration analysis, the trace and maximum eigenvalue statistics reject the null hypothesis at a minimum of 5\% because one co-integration vector exists between GDPs and bank loans to SMEs (or bank loans to LEs). Table 5 presents these estimated co-integration vectors, which are normalized so that the coefficient of each variable is unified.

Figure 1 and Figure2 show the effects of GDP shock on bank loans to SMEs and LEs. The response of bank loans to SMEs from GDP shock is gradually decreasing. However, the response of LEs drops sharply. The results of the impulse-response test show that the impact of GDP shock on SME loan is more persistent that that of LEs.

Table 6 and Table 7 show the results of the variance decomposition test. According to the test results, the variance of SMEs is more susceptible to GDP variance than that of LEs. These results are in line with the results of the impulse-response test.

Table 4: The result of unit root test among aggregate variables

\begin{tabular}{lccc}
\hline \multirow{2}{*}{ Variables } & Optimal time lag & \multicolumn{2}{c}{ Augmented DF } \\
\cline { 2 - 4 } Bank loans to SMEs & $\mathbf{1}$ & level & The differential. \\
Bank loans to LEs & $\mathbf{1}$ & $-0,051$ & $-3,017 * *$ \\
GDP & $\mathbf{1}$ & $-1,418$ & $-13,238 * * *$ \\
\hline Variables & Optimal time lag & $-1,722$ & Phillips-Perron \\
\cline { 3 - 4 } & & level & The differential. \\
Bank loans to SMEs & $\mathbf{1}$ & 0,015 & $-3,017 * * *$ \\
Bank loans to LEs & $\mathbf{1}$ & $-1,438$ & $-5,435 * * *$ \\
GDP & $\mathbf{1}$ & $-2,217$ & $-18,485 * * *$
\end{tabular}

Note:

$* * *, * *$, and $*$ denote significant $1 \%, 5 \%$, and $10 \%$ respectively

Each critical value per level of significance of Augmented DF and Phillips-Perron is $-2,62(10 \%),-2,96(5 \%)$, and $-3,67(1 \%)$ respectively

The optimal time lag of each time series is determined to minimize Schwarz criteria

Table 5: The result of co-integration test among aggregate variables

\begin{tabular}{|c|c|c|c|c|c|c|c|}
\hline \multicolumn{8}{|c|}{ Co-integration between bank loans to SMEs and GDP } \\
\hline Trace statistic & $\begin{array}{c}\text { 5percent } \\
\text { critical value }\end{array}$ & $\begin{array}{c}\text { 1percent } \\
\text { critical } \\
\text { value }\end{array}$ & $\begin{array}{c}\text { Hypothesized } \\
\text { number of Co- } \\
\text { integrating } \\
\text { equations(r) }\end{array}$ & $\begin{array}{c}\text { Max-eigen } \\
\text { statistic }\end{array}$ & $\begin{array}{c}\text { 5percent } \\
\text { critical } \\
\text { value }\end{array}$ & $\begin{array}{l}\text { 1percent } \\
\text { critical } \\
\text { value }\end{array}$ & $\mathbf{H}_{0} \mid \mathbf{H}_{1}$ \\
\hline $34,48 * * *$ & 25,32 & 30,45 & $\mathrm{r}=0$ & $29,10 * *$ & 18,96 & 23,65 & $\mathrm{r}=0 \mid \mathrm{r} \leq 1$ \\
\hline 5,38 & 12,25 & 16,26 & $\mathrm{r} \leq 1$ & 5,38 & 12,25 & 16,26 & $\mathrm{r}=1 \mid \mathrm{r} \leq 2$ \\
\hline \multicolumn{8}{|c|}{ Co-integration between bank loans to LEs and GDP } \\
\hline Trace statistic & $\begin{array}{c}\text { 5percent } \\
\text { critical value }\end{array}$ & $\begin{array}{l}\text { 1percent } \\
\text { critical } \\
\text { value }\end{array}$ & $\begin{array}{c}\text { Hypothesized } \\
\text { number of Co- } \\
\text { integrating } \\
\text { equations(r) }\end{array}$ & $\begin{array}{l}\text { Max- } \\
\text { eigenvalue } \\
\text { statistic }\end{array}$ & $\begin{array}{l}\text { 5percent } \\
\text { critical } \\
\text { value }\end{array}$ & $\begin{array}{c}\text { 1percent } \\
\text { critical } \\
\text { value }\end{array}$ & $\mathbf{H}_{0} \mid \mathbf{H}_{1}$ \\
\hline $25.78 * *$ & 18,17 & 23,46 & $\mathrm{r}=0$ & $25,71 * *$ & 16,87 & 21,47 & $\mathrm{r}=0 \mid \mathrm{r} \leq 1$ \\
\hline 0.07 & 3,74 & 6,40 & $\mathrm{r} \leq 1$ & 0,07 & 3,74 & 6,40 & $\mathrm{r}=1 \mid \mathrm{r} \leq 2$ \\
\hline
\end{tabular}

Note:

$*(* *)$ denotes rejection of the hypothesis $\left(\mathrm{H}_{0}=\right.$ co-integrating equations exist $)$ at the $5 \%(1 \%)$ level.

The optimal time lag of each time series is one that minimizes Schwarz criteria, and r means rank. 
Response of LOANSMALL to Generalized One

S.D. REALGDP Innovation

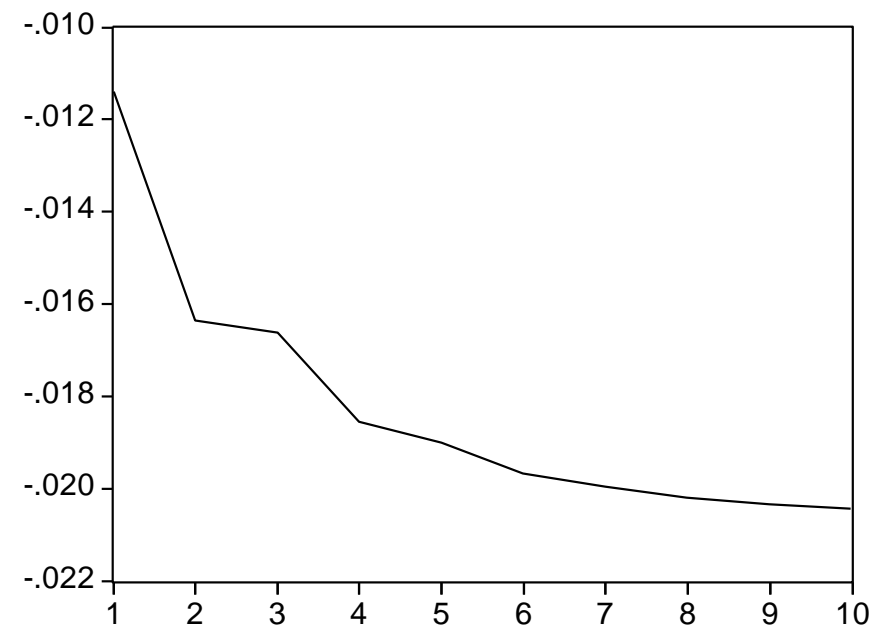

Note: A generalized impulse method that does not depend on VAR ordering is adopted. The generalized impulse responses from an innovation to the $\mathrm{j}$-th variable are derived by applying a variable specific Cholesky factor computed with the $\mathrm{j}$-th variable at the top of the Cholesky ordering

Figure 1: Effect so of result of responses to GDP shock on bank loans to SMEs

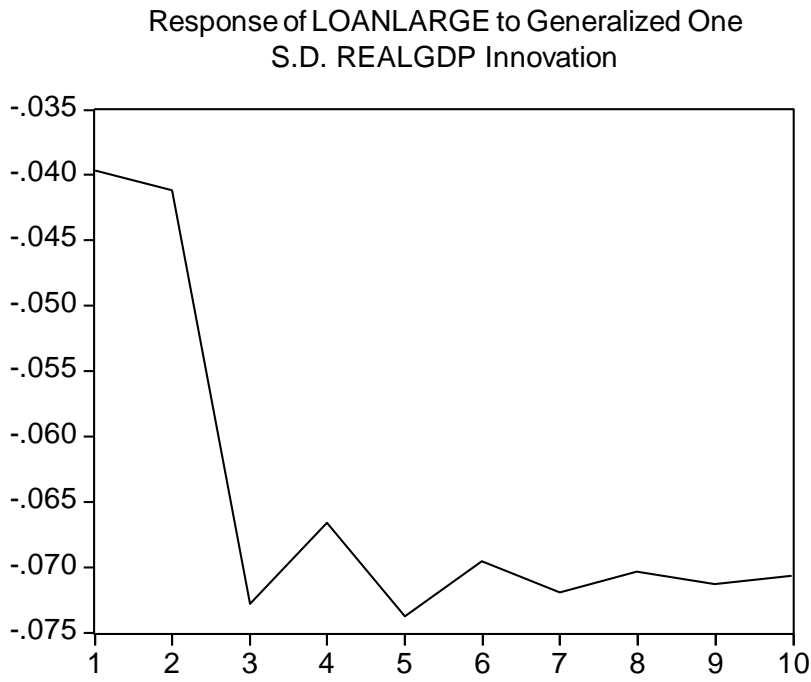

Note: A generalized impulse method that does not depend on VAR ordering. The generalized impulse responses from an innovation to the $j$-th variable are derived by applying a variable specific Cholesky factor computed with the $j$-th variable at the top of the Cholesky ordering

<Figure 2> Effects of responses to GDP shock on bank loans to LEs

Table 6: Variance decomposition analysis of bank loans to SMEs and GDP

\begin{tabular}{ccccc}
\hline Period & S.E. & LOANSMALL & REALGDP \\
\hline 1 & 0,020782 & 100,0000 & 0,000000 \\
2 & 0,037914 & 99,89500 & 0,105001 \\
3 & 0,052994 & 99,29809 & 0,701913 \\
4 & 0,067435 & 99,02205 & 0,977949 \\
5 & 0,080663 & 98,75636 & 1,243643 \\
6 & 0,092943 & 98,57831 & 1,421687 \\
7 & 0,104301 & 98,43691 & 1,563095 \\
8 & 0,114873 & 98,33084 & 1,669162 \\
10 & 0,124749 & 98,24709 & 1,752907 \\
\end{tabular}


Table 7: Variance decomposition analysis of bank loans to LEs and GDP

\begin{tabular}{ccccc}
\hline Period & S.E. & LOANLARGE & REALGDP \\
\hline 1 & 0,073220 & 100,0000 & 0,000000 \\
2 & 0,116632 & 99,37701 & 0,622987 \\
3 & 0,163530 & 99,01874 & 0,981264 \\
4 & 0,197093 & 99,13222 & 0,867777 \\
5 & 0,228097 & 98,95156 & 1,048444 \\
6 & 0,253922 & 98,95613 & 1,043870 \\
7 & 0,278038 & 98,90481 & 1,095189 \\
8 & 0,299777 & 98,89972 & 1,100283 \\
9 & 0,320290 & 98,87973 & 1,120272 \\
10 & 0,339420 & 98,87334 & 1,126663 \\
\hline
\end{tabular}

Table 8 and Table 9 show the result of the causality test of the relationship between bank loans and GDP. According to the results, bank loans to SMEs affect GDP and are affected by GDP. However, bank loans to LEs are not influenced by GDP. In the light of the test results, we presume that bank loans to SMEs are influenced by fluctuation in business cycle.

\section{The rolling VECM's test results for bank loans}

\section{GDP as level variable}

Table 10 presents coefficients of bank loans to SMEs, $\beta_{0}$, and GDP at time t-1. They are significantly positive in the window period of (1) (3) at shows 10,32, 4,55, and 44,37, respectively. This suggests that a positive relationship exists between lending behaviors to SMEs and the business cycle as the level variable, which is called the hypothesis of procyclicality. Hence, the results shows that bank loans to SMEs tend to increase in a booming economy.

However, coefficients of bank loans to SMEs in the window period of $(4) \sim(6)$ are significantly negative registering as $15,88,-11,24$, and $-16,12$, which shows a positive relationship between the level of GDP and the change in the number of bank loans to SMEs. At that time, the balance between change in loans to SMEs and level of GDP is collapsed; $\alpha_{0}$ represents error correction and shows negative coefficients in the window period of (4) $\sim(6)$; it is statistically significant at a $1 \%$ or $5 \%$ level at $-0,03,-0,05$, and $-0,03$. As the product of the speed of adjustment and the coefficient to GDP, $\alpha_{0} \times \beta_{0}$, which is the strength of dynamic stability for equilibrium between the first differentials of bank loans to SMEs and GDP level, is positive, and the change rate of SMEs loans at time $t, \Delta$ Loan ${ }_{\text {SMEs,t }}$ is adjusted to balance. In other words, the balance error is adjusted for GDP level and the first differentials of bank loans to SMEs. If $\alpha_{0}$ is 0 , there is no disequilibrium error between GDP and bank loans to SMEs occurring in the former period. Accordingly, if analysis is conducted based on a vector autoregressive (VAR) model without adjustment of balance errors, a positive linear relationship is not considered between the first differentials of bank loans to SMEs and the GDP level.

Because $\beta_{0}$ is a significant positive in all window periods, considering that $\alpha_{0}$ is statistically significant to make $\alpha_{0} \times \beta_{0}$ directed positively, it confirms that the change in bank loans to SMEs tend to co-move depending on what the business cycle is. Thus, bank loans to SMEs are procyclical.

Table 11 shows whether or not bank loans to LEs have procyclicality. $\beta_{0}$ is significantly negative in the window period of (1) (4) except for (5) and (6). This suggests that the more business cycle upturns (or downturns), the smaller (or larger) the change in loans to LEs become. However, $\beta_{0}$ is unstable because it is positive in the window periods of (5) and (6). Based on the sign of the window period (1) (4), it might be negative in the periods of (5) and (6). If the negative relationship in the case of the window periods (5) and (6) is collapsed, $\alpha_{0}$ should be worked to make $\alpha_{0} \times \beta_{0}$ directed to negative. However, there is no significance in the coefficients of $\alpha_{0}$. In other words, there is no adjustment to balance in the case of the window periods (5) and (6), which show positive coefficients of LEs loan at time $\mathrm{t}-1$.

Therefore, the change in bank loans to LEs has very little to do with the business cycle, and the procyclicality hypothesis is not confirmed in the case of bank loans to LEs.

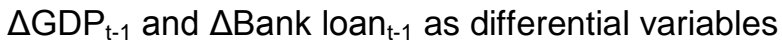

Table 10 also presents the short-term dynamics among differential variables. In all window periods, $\beta_{2}$ is statistically and positively significant at a level of $1 \%$. Thus, the change in loans in the former period provides sufficient explanation with regard to expected changes in loans to SMEs.

However, $\beta_{2}$ is insignificant and negative in Table 11, showing the short-term dynamics among differential variables. In contrast to the case of bank loans to SMEs, the change in loans to LEs does not provide information to expect the change in bank loans to LEs at time t.

Let us review the change of GDP in the previous period. Table 10 shows that $\beta_{3}$ in window period (4) $\sim(6)$ is statistically significant, but not in $(1) \sim(3)$. This suggests that the short-term relationship between $\Delta \mathrm{GDP}_{\mathrm{t}-1}$ and loan to SMEs $_{\mathrm{t}}$ is excessive in a negative direction during the period of $(4) \sim(6)$. Thus, it should be adjusted to a positive direction by working the strength of dynamic stability for balance between the first differential of bank loans to SMEs and the GDP level. As reviewed earlier, $\alpha_{0}$, the speed of the adjustment factor is statistically significant at a minimum level of $5 \%$ in the period (4) (6). 
Table 8: Granger causality test between bank loans to SMEs and GDP

\begin{tabular}{ccc}
\hline Null Hypothesis & F-Statistic & Probability \\
\hline GDP does not Granger Cause SMEs loan & 7,89282 & 0,00063 \\
SMEs loan does not Granger Cause GDP & 2,95669 & 0,04681 \\
\hline
\end{tabular}

Table 9: Granger causality test between bank loans to LEs and GDP

\begin{tabular}{cccc}
\hline Null Hypothesis & F-Statistic & Probability \\
\hline GDP does not Granger Cause LEs loan & 1,07098 & 0,39822 \\
LEs loan does not Granger Cause GDP & 2,55461 & 0,07247 \\
\hline
\end{tabular}

Table 10: Analysis of lending behavior on bank loans to SMEs

$\Delta \operatorname{Loan}_{\mathrm{SMEs}, \mathrm{t}}=\alpha_{0}\left(\ln \operatorname{Loan}_{\mathrm{SMEs}, \mathrm{t}-1}+\beta_{0} \ln \mathrm{GDP}_{\mathrm{t}-1}+\beta_{1} @ \operatorname{trend}_{\mathrm{t}}+\gamma\right)+\beta_{2} \Delta \operatorname{Loan}_{\mathrm{SMEs}, \mathrm{t}-1}$ $+\beta_{3} \Delta \mathrm{GDP}_{\mathrm{t}-1}+\delta+\beta_{4} \operatorname{Control}\left(\mathrm{BIS}_{\mathrm{t}}\right)+\beta_{5} \operatorname{Control}\left(\mathrm{ABD}_{\mathrm{t}}\right)+\beta_{6} \operatorname{Control}\left(\mathrm{NIM}_{\mathrm{t}}\right)$

\begin{tabular}{|c|c|c|c|c|c|c|c|c|c|c|c|c|}
\hline \multirow{2}{*}{ Coefficient of speed of adjustment $\left(\alpha_{0}\right)$} & \multicolumn{2}{|c|}{ (1) } & \multicolumn{2}{|c|}{ (2) } & \multicolumn{2}{|c|}{ (3) } & \multicolumn{2}{|c|}{ (4) } & \multicolumn{2}{|c|}{ (5) } & \multicolumn{2}{|c|}{ (6) } \\
\hline & 0,01 & & 0,02 & & 0,00 & & $-0,03$ & $* *$ & $-0,05$ & $* * *$ & $-0,03$ & $* * *$ \\
\hline & $(0,62)$ & & $(0,37)$ & & $(0,96)$ & & $(-2,10)$ & & $(-2,57)$ & & $(-2,61)$ & \\
\hline $\operatorname{lnGDP}_{t-1}$ & 10,32 & $* * *$ & 4,55 & $* * *$ & 44,37 & $* * *$ & $-15,88$ & $* * *$ & $-11,24$ & $* * *$ & $-16,12$ & $* * *$ \\
\hline & $(5,80)$ & & $(5,86)$ & & $(5,46)$ & & $(-4,71)$ & & $(-4,61)$ & & $(-5,38)$ & \\
\hline @ $\operatorname{trend}_{\mathrm{t}}($ time trend) & $-0,15$ & $* * *$ & $-0,09$ & $* * *$ & $-0,55$ & $* * *$ & 0,15 & $* * *$ & $\mathbf{0 , 1 0}$ & $* * *$ & 0,16 & $* * *$ \\
\hline & $(-6,20)$ & & $(-8,69)$ & & $(-5,02)$ & & $(3,44)$ & & $(3,12)$ & & $(4,23)$ & \\
\hline Intercept $(\gamma)$ & $-138,0$ & & $-68,6$ & & $-547,3$ & & 176,9 & & 121,1 & & 179,6 & \\
\hline$\Delta$ Loan $_{\mathrm{SMEs,t-1}}$ & $\mathbf{0 , 5 3}$ & $* * *$ & $\mathbf{0 , 5 3}$ & $* * *$ & 0,55 & $* * *$ & 0,62 & $* * *$ & 0,63 & $* * *$ & 0,65 & $* * *$ \\
\hline & $(-0,66)$ & & $(-0,58)$ & & $(-0,36)$ & & $(-0,22)$ & & $(-0,49)$ & & $(-0,37)$ & \\
\hline$\Delta \mathrm{GDP}_{\mathrm{t}-1}$ & $-0,09$ & & $-0,07$ & & $-0,11$ & & $-0,25$ & $* *$ & $-0,31$ & $* * *$ & $-0,32$ & $* * *$ \\
\hline & $(-0,80)$ & & $(-0,60)$ & & $(-1,01)$ & & $(-2,18)$ & & $(-2,68)$ & & $(-2,71)$ & \\
\hline Constant $(\delta)$ & 0,03 & & 0,07 & & 0,01 & & $\mathbf{0 , 3 0}$ & & 0,75 & & 0,75 & \\
\hline & $(0,06)$ & & $(0,15)$ & & $(\mathbf{0 , 0 1})$ & & $(0,69)$ & & $(1,36)$ & & $(1,36)$ & \\
\hline $\mathrm{BIS}_{\mathrm{t}}$ & 0,00 & & $\mathbf{0 , 0 0}$ & & 0,00 & & 0,00 & & $-0,00$ & & 0,00 & \\
\hline & $(0,44)$ & & $(0,39)$ & & $(0,47)$ & & $(0,14)$ & & $(-0,29)$ & & $(0,31)$ & \\
\hline $\mathrm{ABD}_{\mathrm{t}}$ & $-0,01$ & & $-0,01$ & & $-0,01$ & & $-0,02$ & & $-0,04$ & & $-0,04$ & \\
\hline & $(-0,39)$ & & $(-0,51)$ & & $(-0,31)$ & & $(-0,88)$ & & $(-1,49)$ & & $(-1,46)$ & \\
\hline $\mathrm{NIM}_{\mathrm{t}}$ & 0,04 & & $\mathbf{0 , 0 3}$ & & 0,03 & & 0,01 & & $-0,02$ & & $-0,03$ & \\
\hline & $(1,14)$ & & $(1,08)$ & & $(1,12)$ & & $(\mathbf{0 , 3 5})$ & & $(-0,58)$ & & $(-0,91)$ & \\
\hline Adj. $R^{2}$ & 0,15 & & 0,15 & & 0,17 & & 0,27 & & $\mathbf{0 , 3 3}$ & & $\mathbf{0 , 3 3}$ & \\
\hline H.S. $(\mathrm{df}=36)$ & 46,10 & & 44,25 & & 44,79 & & 44,70 & & 44,93 & & 46,52 & \\
\hline & $(0,12)$ & & $(0,16)$ & & $(0,15)$ & & $(0,15)$ & & $(0,15)$ & & $(0,11)$ & \\
\hline
\end{tabular}

\footnotetext{
Note:

$* * *$ is statistically significant at $1 \%, * *$ at $5 \%$ and $*$ at $10 \%$. is referred to as loans to SMEs, GDP is real Gross Domestic Product, @trend and $\gamma$ mean time trend and intercept within co-integration vector. BIS, ABD, NIM mean BIS ratio, allowance for bad debts, and net interest margin, respectively. In $\alpha_{0}\left(\ln L o a n_{\text {SMEs, } t-1}+\beta_{0} \ln G D P_{t-1}+\beta_{1} @\right.$ trend $\left._{t}+\gamma\right)$, the parenthesis is an equilibrium error in the previous time; this co-integration vector is standardized as one of

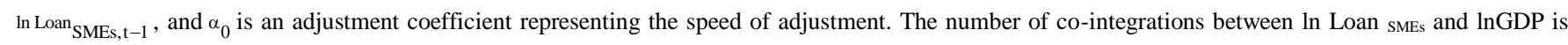
confirmed with Max-eigenvalue statistics. Optimal time difference within the model is 1, which is the result of determination of the time difference based on SC (Schwartz Bayesian criteria). H.S. means heteroskedasticity chi square statistic based on a quadratic trend model. The parenthesis represents t-statistics. (1)

$\sim$ (6) means window period increases by 1 -quarter from $1999.4 \mathrm{q} \sim 2007.3 \mathrm{q}$ to $2001.1 \mathrm{q} \sim 2008.4 \mathrm{q}$.
} 
Table 11: Analysis of lending behavior on bank loans to LEs

The rolling VECM Model (Data for bank loans to LEs) :

$$
\begin{aligned}
& \Delta \operatorname{Loan}_{\mathrm{LEs}, \mathrm{t}}=\alpha_{0}\left(\ln L o a n_{\mathrm{LEs}, \mathrm{t}-1}+\beta_{0} \ln \mathrm{GDP}_{\mathrm{t}-1}+\beta_{1} @ \operatorname{trend}_{\mathrm{t}}+\gamma\right)+\beta_{2} \Delta \operatorname{Loan}_{\mathrm{LEs}, \mathrm{t}-1} \\
& +\beta_{3} \Delta \mathrm{GDP}_{\mathrm{t}-1}+\delta+\beta_{4} \operatorname{Control}\left(\mathrm{BIS}_{\mathrm{t}}\right)+\beta_{5} \operatorname{Control}\left(\mathrm{ABD}_{\mathrm{t}}\right)+\beta_{6} \operatorname{Control}\left(\mathrm{NIM}_{\mathrm{t}}\right)
\end{aligned}
$$

\begin{tabular}{|c|c|c|c|c|c|c|c|c|c|c|c|c|}
\hline \multirow[b]{2}{*}{ Coefficient of speed of adjustment $\left(\alpha_{0}\right)$} & \multicolumn{2}{|c|}{ (1) } & \multicolumn{2}{|c|}{ (2) } & \multicolumn{2}{|c|}{ (3) } & \multicolumn{2}{|c|}{ (4) } & \multicolumn{2}{|l|}{ (5) } & \multicolumn{2}{|l|}{ (6) } \\
\hline & $\mathbf{0 , 0 2}$ & & $\mathbf{0 , 0 3}$ & & $\mathbf{0 , 0 2}$ & & $\overline{0,00}$ & & 0,00 & & $\mathbf{0 , 0 0}$ & \\
\hline & $(0,66)$ & & $(0,73)$ & & $(0,77)$ & & $(\mathbf{0 , 2 0 )}$ & & $(\mathbf{0 , 5 4 )}$ & & $(\mathbf{0 , 5 5 )}$ & \\
\hline \multirow[t]{2}{*}{$\operatorname{lnGDP}_{\mathrm{t}-1}$} & $-15,62$ & $* * *$ & $-12,02$ & $* * *$ & $-21,44$ & $* * *$ & $-66,86$ & $* * *$ & 110,19 & $* * *$ & 304,88 & $* * *$ \\
\hline & $(-6,17)$ & & $(-6,32)$ & & $(-6,12)$ & & $(-5,64)$ & & $(5,66)$ & & $(6,17)$ & \\
\hline$@ \operatorname{trend}_{\mathrm{t}}($ time trend) & $\mathbf{0 , 2 0}$ & & 0,15 & & $\mathbf{0 , 2 7}$ & & $\mathbf{0 , 7 5}$ & & $-1,22$ & & $-3,39$ & \\
\hline Intercept $(\gamma)$ & 174,8 & & 131,6 & & 244,7 & & 791,4 & & $-1,338,2$ & & $-3,679,8$ & \\
\hline \multirow[t]{2}{*}{$\Delta$ Loan $_{\text {LEs,t-1 }}$} & $-0,15$ & & $-0,13$ & & $-0,08$ & & $-0,05$ & & $-0,10$ & & $-0,08$ & \\
\hline & $(-0,66)$ & & $(-0,58)$ & & $(-0,36)$ & & $(-0,22)$ & & $(-0,49)$ & & $(-0,37)$ & \\
\hline \multirow[t]{2}{*}{$\Delta \mathrm{GDP}_{\mathrm{t}-1}$} & $\mathbf{0 , 5 0}$ & $*$ & $\mathbf{0 , 5 2}$ & $* *$ & $\mathbf{0 , 5 9}$ & $* *$ & 0,42 & & 0,10 & & 0,12 & \\
\hline & $(1,65)$ & & $(1,77)$ & & $(\mathbf{1 , 9 3 )}$ & & $(\mathbf{1 , 1 3})$ & & $(0,27)$ & & $(\mathbf{0 , 3 2})$ & \\
\hline \multirow[t]{2}{*}{ Constant $(\delta)$} & $-1,02$ & & $-0,95$ & & $-0,97$ & & $-0,71$ & & 0,93 & & $\mathbf{0 , 8 0}$ & $* *$ \\
\hline & $(-0,71)$ & & $(-0,66)$ & & $(-0,67)$ & & $(-0,47)$ & & $(\mathbf{0 , 5 1 )}$ & & $(\mathbf{1 , 7 6 )}$ & \\
\hline \multirow[t]{2}{*}{$\mathrm{BIS}_{\mathrm{t}}$} & $-0,01$ & & $-0,01$ & & $-0,03$ & & $-0,03$ & & $-0,03$ & $*$ & $-0,03$ & \\
\hline & $(-0,19)$ & & $(-0,41)$ & & $(-1,19)$ & & $(-1,38)$ & & $(-1,45)$ & & $(-1,26)$ & \\
\hline \multirow[t]{2}{*}{$\mathrm{ABD}_{\mathrm{t}}$} & 0,04 & & 0,04 & & 0,05 & & 0,04 & & $-0,04$ & & $-0,03$ & \\
\hline & $(0,50)$ & & $(\mathbf{0 , 5 1 )}$ & & $(0,69)$ & & $(0,54)$ & & $(-0,42)$ & & $(-0,35)$ & \\
\hline \multirow[t]{2}{*}{$\mathrm{NIM}_{\mathrm{t}}$} & 0,14 & $*$ & 0,13 & $*$ & 0,12 & & 0,09 & & $-0,03$ & & $-0,05$ & \\
\hline & $(1,42)$ & & $(1,39)$ & & $(1,25)$ & & $(\mathbf{0 , 8 5})$ & & $(-0,27)$ & & $(-0,34)$ & \\
\hline $\operatorname{Adj} . R^{2}$ & 0,17 & & 0,20 & & 0,31 & & 0,35 & & 0,46 & & 0,42 & \\
\hline \multirow[t]{2}{*}{ H.S. $(\mathrm{df}=36)$} & 48,39 & & 48,45 & & 48,71 & & 48,90 & & 48,61 & & 44,89 & \\
\hline & $(0,23)$ & & $(0,23)$ & & $(0,22)$ & & $(0,22)$ & & $(0,22)$ & & $(0,35)$ & \\
\hline
\end{tabular}

Note:

*** is statistically significant at $1 \%, * *$ at $5 \%$ and $*$ at $10 \%$. is referred to as loans to LEs, GDP is real Gross Domestic Product, @ trend and $\gamma$ mean time trend and intercept within co-integration vector. BIS, ABD, NIM mean BIS ratio, allowance for bad debts, and net interest margin, respectively. In $\alpha_{0}\left(\ln L o a n_{L E s, t-1}+\beta_{0} \ln _{\text {GDP }}+1+\beta_{1} @\right.$ trend $\left._{t}+\gamma\right)$, the parenthesis is an equilibrium error in the previous time; this co-integration vector is standardized as one of $\ln _{\text {Loan }}{ }_{\text {LEs, } t-1}$, and $\alpha_{0}$ is an adjustment coefficient representing the speed of adjustment. The number of co-integrations between ln Loan LEs and, lnGDP is confirmed with Max-eigenvalue statistics. Optimal time difference within the model is 1, which is the result of determination of the time difference based on SC (Schwartz Bayesian criteria). H.S. means heteroskedasticity chi square statistic based on a quadratic trend model. The parenthesis represents t-statistics. (1) $\sim$ (6) means the window period increase by 1-quarter from 1999.4q 2007.3q to 2001.1q 2008.4q.

Therefore, the short-term dynamics between $\Delta$ bank loans to $\mathrm{SMEs}_{\mathrm{t}}$ and $\triangle \mathrm{GDP}_{\mathrm{t}-1}$ have significance. Namely, the change of GDP in former periods affects significantly and negatively current $\triangle$ bank loans to SMEs.

Table 11 shows that all $\beta_{3}$ of window period of $(1) \sim(3)$ are positive and statistically significant at a $5 \%$ level of 0.50 and 0.59 respectively. This means that the change in the lagged GDP contributes to a positive relationship with the change in LEs loans at time t.

However, it also shows that there is no relationship between $\Delta$ bank loan to $\mathrm{LEs}_{\mathrm{t}}$ and $\Delta \mathrm{GDP}_{\mathrm{t}-1}$ in the window period of (4) $\sim$ (6). In particular, all $\alpha_{0}$, the speed of adjustment factor in the window period $(1) \sim(3)$ do not work to balance the first differentials of bank loans to LEs and GDP level as in the case of bank loans to SMEs. They are not significant; thus, it is suggested that $\Delta$ bank loans to $\mathrm{LEs}_{\mathrm{t}}$ have little do with $\Delta \mathrm{GDP}_{\mathrm{t}-1}$.

\section{The rolling VECM's test results for control variables}

\section{BIS ratio}

In Table 10 shows that all $\beta_{4}$ are 0.00 in all window periods. The BIS ratio was included as a control variable in order to analyze procyclicality as a proxy of capital adequacy. The BIS ratio is insignificantly affected by changes in bank loans to SMEs. At first, it was expected that the higher (or lower) the BIS ratio, the smaller (or larger) the loan to SMEs becomes because the stronger the requests for capital adequacy, the more efforts banks make to reduce risky assets, is not true in this study.

In Table 11, all $\beta_{4}$ are also generally insignificant except for the window period (5), which shows a negative sign (-0.03), meaning that the higher (or lower) the BIS ratio, the smaller (or larger) the loans to LEs become. However, all window periods except for (5), show that the BIS ratio is not related 
to the lending behavior of Korean banks over the business cycle.

In light of the above results, it is understood that $\Delta$ bank loan to $\mathrm{SMEs}_{\mathrm{t}}$ and to $\mathrm{LEs}_{\mathrm{t}}$ does not react steadily in all periods when the BIS ratio is control variable in a change of business cycle.

\section{ABD}

The amount of ABD was considered a control variable in existing studies (Albertazzi \& Gambacorta, 2009; Salas \& Saurina, 2002; Laeven \& Majnoni, 2003), but in the present study changes in ABD did not affect changes in loan to SMEs. Table 10 and Table 11 show that the estimated coefficients $\left(\bigcap_{5}\right)$ had no statistical significance.

\section{NIM}

NIM was also included in the analysis model as a control variable that is affected by commercial interest rates and inducement of capital, but it was not statistically significant in the case of analysis of bank loans to SMEs. Table 10 shows that $\beta_{6}$ is not significant. Therefore, the current NIM does not have a significant effect on the decision behavior in the financing of SMEs by Korean banks.

Table 11 also shows that $\beta_{6}$ is not significant in the window periods considering the current time even though it presents positive signs, 0,14 and 0,13 respectively at the $10 \%$ level in window periods (1) and (2).

\section{Robustness checks}

To confirm the robustness of this rolling VECM, heteroskedasticity test results are presented in the last column of Table 10 and Table 11. In general, heteroskedasticity has serious consequences for time series analysis. Although the estimator remains unbiased, the estimated standard errors may be wrong, thus estimator is no longer BLUE. It suggests that all H.S. (heteroskedasticity chi square statistic) do not reject the null hypothesis $\left(\mathrm{H}_{0}\right.$ means that there is no heteroskedasticity in the residual term.) in all window periods. Therefore, the estimated coefficients derived from this model are reliable.

\section{Panel data analysis results}

\section{Panel GLS model}

This model is considered a first-order autoregressive model in which random errors have a structure of heteroskedasticity, the contemporaneously correlated, and autoregression. This model is as follows. Banks are denoted as subscript $\mathrm{i}=1, \ldots, \mathrm{N}$, and time as $\mathrm{t}=1, \ldots, \mathrm{T} ; \mathrm{K}$ is the number of exogenous or independent variables. The detailed description of this model is as shown.

$$
\begin{aligned}
& \Delta \operatorname{Loan}_{\text {SMEs }\left(\text { or_LEs }_{2}, \mathrm{i}, \mathrm{t}\right.}=\sum_{\mathrm{k}=1}^{\mathrm{K}} \beta_{\mathrm{k}} \mathrm{X}_{\mathrm{i}, \mathrm{t}-\mathbf{1}, \mathrm{k}}+\varepsilon_{\mathrm{i}, \mathrm{t}} \\
& \left(\mathrm{i}=\mathbf{1}, \ldots, \mathrm{N} ; \mathrm{t}=\mathbf{1}, \ldots, \mathrm{T} ; \mathrm{k}=\mathbf{1} \ldots ., \mathrm{K} ; \varepsilon_{\mathrm{i}, \mathrm{t}}=\rho_{\mathrm{i}} \varepsilon_{\mathrm{i}, \mathrm{t}}+\mathrm{u}_{\mathrm{i}, \mathrm{t}}\right)
\end{aligned}
$$

In this model, the covariance matrix of vector of random residuals is as follows. To determine the beta, calculate the covariance matrix $\mathrm{V}$ as shown below.

$\mathrm{E}\left(\varepsilon_{-} \varepsilon^{\prime}\right)=$ Variance $=\left(\begin{array}{ccc}\sigma_{11} \mathrm{P}_{11} & \cdots & \sigma_{1 \mathrm{~N}} \mathrm{P}_{1 \mathrm{~N}} \\ \vdots & \ddots & \vdots \\ \sigma_{\mathrm{N} 1} \mathrm{P}_{\mathrm{N} 1} & \cdots & \sigma_{\mathrm{NN}} \mathrm{P}_{\mathrm{NN}}\end{array}\right)$,

where

$\mathrm{P}_{\mathrm{ij}}=\left(\begin{array}{ccc}1 \cdot \rho^{0} & \cdots & \mathbf{1} \cdot \rho_{\mathrm{j}}^{\mathrm{T}-1} \\ \vdots & \ddots & \vdots \\ 1 \cdot \rho_{\mathrm{j}}{ }^{\mathrm{T}-1} & \cdots & 1 \cdot \rho^{0}\end{array}\right)$

The covariance matrix is estimated by a two-stage procedure leading to the estimation of model regression parameters by the generalized least squares (GLS) method. The variance is estimated in a two-step procedure. The first step involves the use of ordinary least squares to estimate $\beta$, and the obtained fitted residuals are as follows.

$\hat{\varepsilon}=\Delta \operatorname{Loan}_{\left.\mathrm{SME}_{(\mathrm{or}}-\mathrm{LE}\right)}-\mathrm{X} \hat{\beta}_{\mathrm{OLS}}$

A consistent estimator of the first-order autoregressive parameter is then obtained as follows.

$\hat{\rho}_{i}=\left(\sum_{t=2}^{T} \hat{\varepsilon}_{i, t} \hat{\varepsilon}_{i, t-1}\right) /\left(\sum_{t=2}^{T} \hat{\varepsilon}_{i, t-1}{ }^{2}\right)(i=1, \ldots, N)$

To remove the autoregressive characteristic of the data, (6) is derived from (1) less (5) plus the estimated autoregressive parameter.

$$
\begin{aligned}
& \Delta \operatorname{Loan}_{\mathrm{i}, \mathrm{t}}-\hat{\rho}_{\mathrm{i}} \Delta \operatorname{Loan}_{\mathrm{i}, \mathrm{t}-1}=(1) \sum_{\mathrm{k}=1}^{\mathrm{P}}\left(\mathrm{X}_{\mathrm{i}, \mathrm{t}, \mathrm{k}}\right) \beta_{\mathrm{k}}+ \\
& \varepsilon_{\mathrm{i}, \mathrm{t}}-(5) \sum_{\mathrm{k}=1}^{\mathrm{P}}\left(\hat{\rho}_{\mathrm{i}} \mathrm{X}_{\mathrm{i}, \mathrm{t}}-1, \mathrm{k}\right) \beta_{\mathrm{k}}+\varepsilon_{\mathrm{i}, \mathrm{t}}-1 \hat{\rho}_{\mathrm{i}} \\
& \Delta \operatorname{Loan}_{\mathrm{i}, \mathrm{t}}-\hat{\rho}_{\mathrm{i}} \Delta \operatorname{Loan}_{\mathrm{i}, \mathrm{t}-1}=\sum_{\mathrm{k}=1}^{\mathrm{P}}\left(\mathrm{X}_{\mathrm{i}, \mathrm{t}, \mathrm{k}}\right)_{\mathrm{k}}- \\
& \left.\hat{\rho}_{\mathrm{i}} \mathrm{X}_{\mathrm{i}, \mathrm{t}-1, \mathrm{k}}\right) \beta_{\mathrm{k}}+\varepsilon_{\mathrm{i}, \mathrm{t}}-\hat{\rho}_{\mathrm{i}} \varepsilon_{\mathrm{i}, \mathrm{t}-1}
\end{aligned}
$$

where

(6) replaces $\Delta \operatorname{Loan}_{\mathrm{i}, \mathrm{t}}-\hat{\rho}_{\mathrm{i}} \Delta \operatorname{Loan}_{\mathrm{i}, \mathrm{t}-1}$ by $\Delta \operatorname{Loan}_{\mathrm{i}, \mathrm{t}}{ }^{*}$, $X_{i, t, k}-\hat{\rho}_{i} X_{i, t-1, k}$ by $X_{i, t, k}{ }^{*}$, and $\varepsilon_{i, t}-\hat{\rho}_{i} \varepsilon_{i, t-1}$ by $\varepsilon_{i, t}{ }^{*}$ respectively, and thus is called (7).

$\Delta \operatorname{Loan}_{\mathrm{i}, \mathrm{t}}{ }^{*}=\sum_{\mathrm{k}=1}^{\mathrm{P}} \mathrm{X}_{\mathrm{i}, \mathrm{t}, \mathrm{k}}^{*} \beta_{\mathrm{k}}+\varepsilon_{\mathrm{i}, \mathrm{t}}^{*}$

The second step in estimating the covariance matrix is to apply ordinary least squares to the preceding transformed model, (7) $\Delta \operatorname{Loan}_{\mathrm{i}, \mathrm{t}}{ }^{*}=\sum_{\mathrm{k}=1}^{\mathrm{P}} \mathrm{X}_{\mathrm{i}, \mathrm{t}, \mathrm{k}}^{*} \beta_{\mathrm{k}}+\varepsilon_{\mathrm{i}, \mathrm{t}}^{*} \quad$ to obtain $\hat{\beta}^{*}{ }_{\text {oLs }}$. By using $\hat{\beta}^{*}$ oLs , calculate $\hat{\varepsilon}^{*}$ as shown below (8). 


$$
\varepsilon^{*}=\Delta \operatorname{Loan}^{*}-\mathrm{X}^{*} \hat{\beta}^{*} \text { oLs }
$$

(9) is derived as $\hat{\phi}_{i, j}^{*}$ by using $\hat{\varepsilon}^{*}$. Finally $\hat{\phi}_{i, j}^{*}$ and $\hat{\rho}_{i}$ of (4) into (10), and $\sigma_{\mathrm{i}, \mathrm{j}}$ can be estimated. Therefore, $\mathrm{E}\left(\varepsilon_{-} \varepsilon^{\prime}\right)$ with $\sigma_{\mathrm{i}, \mathrm{j}}$ is estimated.

$$
\begin{aligned}
& \hat{\phi}_{\mathrm{i}, \mathrm{j}}=1 /(\mathrm{T}-\mathrm{p}) \sum_{\mathrm{t}=1}^{\mathrm{T}} \hat{\varepsilon}_{\mathrm{i}, \mathrm{\varepsilon}}^{*} \hat{\varepsilon}_{\mathrm{j}, \mathrm{t}}^{*} \\
& \sigma_{\mathrm{i}, \mathrm{j}}=\hat{\phi}_{\mathrm{i}, \mathrm{j}} /\left(1-\hat{\rho}_{\mathrm{i}} \hat{\rho}_{\mathrm{j}}\right)
\end{aligned}
$$

\section{Clustering fixed effect model}

This fixed effect used to determine the relationship between GDP, the change in bank loans, and the short-term relationship among differential variables. In this study, the model is used to measure differential bank loans to SMEs or LEs as defined in Table 12 and Table 13.

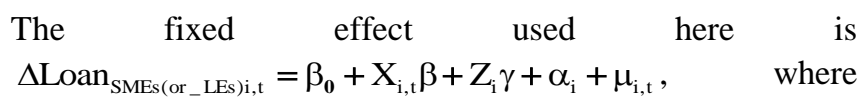
$\Delta \operatorname{Loan}_{\text {SMEs(or_LEs)i,t }}$ is the dependent variable observed for individual $\mathrm{i}$ at time $\mathrm{t}, \mathrm{X}_{\mathrm{i}, \mathrm{t}}$ is the time-variant regressor, $\mathrm{Z}_{\mathrm{i}}$ is the time-invariant regressor, $\alpha_{i}$ is the unobserved bankspecific effects, and $\mu_{\mathrm{i}, \mathrm{t}}$ is the error term. However, in dealing with $\alpha_{i}$, it is assumed that $\alpha_{i}$ is not independent of $\mathrm{X}_{\mathrm{i}, \mathrm{t}} \beta$ and $\mathrm{Z}_{\mathrm{i}}$. The fixed effect model is as follows:

$$
\begin{aligned}
& \Delta \operatorname{Loan}_{\text {SMEs (or_LEs)i,t }}=\beta_{0}+\beta_{1} \Delta \mathrm{GDP}_{\mathrm{t}-1}+\beta_{2} \Delta \mathrm{GDP}_{\mathrm{t}}+ \\
& \beta_{3} \Delta \operatorname{Loan}_{\mathrm{SMES}(\text { or_LEs)i,t-1}}+\beta_{4} \mathrm{CIV}_{\mathrm{SMEs}(\text { or_LEs)t }}+ \\
& \beta_{5} \Delta \mathrm{GDP}_{\mathrm{t}-1} \cdot \mathrm{BIS}_{\mathrm{i}, \mathrm{t}-1+1}+\beta_{6} \Delta \mathrm{GDP}_{\mathrm{t}-1} \cdot \mathrm{NPLi}_{\mathrm{t}-1}+ \\
& \beta_{7} \Delta \mathrm{GDP}_{\mathrm{t}-1} \cdot \mathrm{NIM}_{\mathrm{i}, \mathrm{t}-1}+\beta_{8} \Delta \mathrm{GDP}_{\mathrm{t}-1} \cdot \mathrm{BO}_{1}
\end{aligned}
$$

In this model, $\alpha_{\mathrm{i}}$ and $\mathrm{Z}_{\mathrm{i} \gamma} \gamma$ represent time-invariant bankspecific effects and bank constant time effects respectively. It is assumed that bank-specific effects, $\alpha_{\mathrm{i}}$ are unobservable but have a significant impact on bank loans. These effects change across banks but are fixed for a given bank over time. In contrast, $Z_{i} \gamma$ varies over time but is the same for all banks in a given year.

\section{The result of panel data analysis with panel GLS and the clustering fixed effect model}

\section{CIV(Co-Integrating Vector)}

This analysis focuses on the question of whether or not positive relationship exists between the business cycle and the first differentials of bank loans. As the rolling VECM to aggregated variables shows, bank loans to SMEs are procyclical.

Table 12 shows that as expected, the signs are significantly negative. It provides evidence of a positive relationship between the business cycle and the first differentials of bank loans to SMEs. The coefficients of CIV factors in all models are statistically significant, and their signs are negative. This suggests that the excessively increased $\Delta$ bank loans to $\mathrm{SMEs}_{\mathrm{t}}$ compared with the lagged $\triangle \mathrm{GDP}$ are adjusted for balance in the negative direction. The signs of all lagged $\triangle \mathrm{GDP}$ in all models are negative in the case of panel GLS and the Fixed Effects model even though they are not statistically significant in the Fixed Effects model.

In Table 12, the significance of CIV factors with negative signs suggests that CIV factors work to adjust the balance between the $1^{\text {st }}$ differential of bank loans to SMEs and the GDP level, which is attributed to the break of the short-term relationship between the lagged $\Delta \mathrm{GDP}$ and $\Delta \mathrm{Loan}_{\mathrm{SMEs}}$ at time t. Although the lagged $\Delta$ GDP is insignificant in models 3 and 4 using the Clustering Fixed Effect model, their signs are definitely negative and co-integrating vector (CIV) factors are statistically significant at $10 \%$.

Table 13 presents evidence of whether or not there exists a positive relationship between the business cycle and the first differential of bank loans to LEs. As expected, all coefficients of CIV factors are not statistically significant in all models. These results are in line with those of the rolling VECM, which shows insignificant error correction, $\alpha_{0}$ in all window periods.

In light of this evidence, it is understood that bank loans to LEs over the business cycle are not comoved, and it is suggested that bank loans to LEs are not procyclical, which is consistent with the results of the rolling VECM.

\section{$\Delta$ GDP variables}

Table 12 shows that the relationship between $\Delta$ loan to SMEs at time $t$ and lagged $\triangle$ GDP is negative regardless of models and estimation methods. According to the dynamic model, the rolling VECM, short-term dynamics between lagged $\triangle \mathrm{GDP}$ and current change in loans to SMEs have a negative relationship even though the relationship between the first differential of bank loan to SMEs and GDP level is positive. In the panel analysis, all coefficients of lagged $\Delta$ GDP are negative, which is in line with the results of the rolling VECM. Moreover, the short-term relationship between lagged $\triangle \mathrm{GDP}$ and current $\triangle$ Loans to SMEs is definitely negative and significant at a minimum level of $5 \%$. The short-term relationship among differential variables of GDP and bank loans may be influenced by the marketing strategy of the bank $^{6}$ to make a profit or the credit stabilization of state-owned banks by enhancing relationships with SMEs (Dell'Ariccia \& Marquez, 2001). Thus, despite economic recession, banks tend to increase their loans to SMEs, which are heavily dependent on banks for raising funds.

\footnotetext{
${ }^{6}$ According to Dell'Ariccia and Marquez (2001), bank may hold onto "captured": relationship borrowers during distress periods to reap future benefits from them.
} 
Table 12: The Result of regression Bank loans to SMEs to other independent variables

This table reports Panel GLS and Clustering Fixed Effect model's estimation to bank loans to SMEs. These panel data analysis methods use as major variables such as $\Delta \mathrm{GDP}_{\mathrm{t}-1}, \Delta \mathrm{GDP}_{\mathrm{t}}, \Delta$ Loan SMEs,t,I , and $\mathrm{CIV}_{\mathrm{SMEs}, \mathrm{t}},(\mathrm{CIV}$ factors are derived from cointegration analysis among cross-sectional data of bank and GDP variable) including interaction terms like $\Delta \mathrm{GDP}_{\mathrm{t}-1} \times \mathrm{BIS}_{\mathrm{t}-1, \mathrm{i}}$

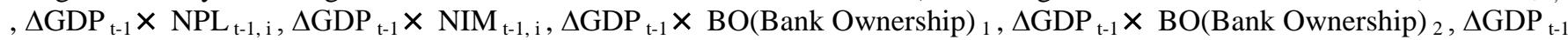
$\times \ln$ size $_{t-1, i}$

\begin{tabular}{|c|c|c|c|c|c|c|c|c|}
\hline \multirow[b]{3}{*}{ Constant } & \multicolumn{4}{|c|}{ Panel GLS Model } & \multicolumn{4}{|c|}{$\begin{array}{c}\text { Clustering Fixed Effect Model } \\
\text { (Clustering: Firm, Year) }\end{array}$} \\
\hline & \multicolumn{2}{|c|}{ Model 1} & \multicolumn{2}{|c|}{ Model 2} & \multicolumn{2}{|c|}{ Model 3} & \multicolumn{2}{|c|}{ Model 4} \\
\hline & 0,019 & $* * *$ & 0,018 & $* * *$ & 0,014 & $* *$ & 0,014 & $* *$ \\
\hline & $(7,09)$ & & $(\mathbf{8 , 1 3})$ & & $(2,11)$ & & $(2,18)$ & \\
\hline \multirow[t]{2}{*}{$\Delta \mathrm{GDP}_{\mathrm{t}-1}$} & $-6,173$ & $*$ & $-5,286$ & $* *$ & $-4,110$ & & $-4,224$ & \\
\hline & $(-1,90)$ & & $(-2,28)$ & & $(-0,65)$ & & $(-0,72)$ & \\
\hline \multirow{2}{*}{$\Delta \mathrm{GDP}_{\mathrm{t}}$} & $-0,222$ & $* * *$ & $-0,212$ & $* * *$ & $-0,274$ & $* * *$ & $-0,262$ & $* *$ \\
\hline & $(-6,39)$ & & $(-7,83)$ & & $(-2,84)$ & & $(-2,80)$ & \\
\hline \multirow[t]{2}{*}{$\Delta$ Loan $_{\mathrm{SMEs}, \mathrm{t}-1, \mathrm{i}}$} & $\mathbf{0 , 3 8 3}$ & $* * *$ & 0,346 & $* * *$ & 0,562 & $* * *$ & 0,521 & $* * *$ \\
\hline & $(5,00)$ & & $(5,08)$ & & $(4,16)$ & & $(3,95)$ & \\
\hline \multirow[t]{2}{*}{ CIV. sMEs,t } & $-0,013$ & $* * *$ & $-0,013$ & $* * *$ & $-0,012$ & $*$ & $-0,011$ & $*$ \\
\hline & $(-3,64)$ & & $(-3,91)$ & & $(-1,69)$ & & $(-1,68)$ & \\
\hline \multirow[t]{2}{*}{$\Delta \mathrm{GDP}_{\mathrm{t}-1} \times \mathrm{BIS}_{\mathrm{t}-1, \mathrm{i}}$} & $-\mathbf{- 0 , 0 3 3}$ & & & & $-0,038$ & & & \\
\hline & $(-1,63)$ & & & & $(-0,79)$ & & & \\
\hline \multirow[t]{2}{*}{$\Delta \mathrm{GDP}_{\mathrm{t}-1} \times \mathrm{NPL}_{\mathrm{t}-1, \mathrm{i}}$} & 0,018 & & & & $\mathbf{0 , 0 3 8}$ & & & \\
\hline & $(0,24)$ & & & & $(\mathbf{0 , 1 7})$ & & & \\
\hline \multirow[t]{2}{*}{$\Delta \mathrm{GDP}_{\mathrm{t}-1} \times \mathrm{NIM}_{\mathrm{t}-1, \mathrm{i}}$} & $-0,154$ & $* * *$ & & & $-0,119$ & & & \\
\hline & $(-3,38)$ & & & & $(-0,92)$ & & & \\
\hline \multirow[t]{2}{*}{$\Delta \mathrm{GDP}_{\mathrm{t}-1} \times \mathrm{BO}_{1}$} & $-0,110$ & $* *$ & $-0,154$ & $* * *$ & $-0,105$ & & $-\mathbf{0 , 1 3 7}$ & \\
\hline & $(-2,33)$ & & $(-3,34)$ & & $(-0,91)$ & & $(-1,32)$ & \\
\hline \multirow[t]{2}{*}{$\Delta \mathrm{GDP}_{\mathrm{t}-1} \times \mathrm{BO}_{2}$} & $-0,281$ & $* * *$ & $-0,229$ & $* * *$ & $-0,277$ & & $-0,251$ & \\
\hline & $(-2,57)$ & & $(-3,03)$ & & $(-1,35)$ & & $(-1,34)$ & \\
\hline \multirow[t]{2}{*}{$\Delta \mathrm{GDP}_{\mathrm{t}-1} \times \ln \operatorname{size}_{\mathrm{t}-1, \mathrm{i}}$} & $\mathbf{0 , 3 7 3}$ & $* *$ & 0,287 & $* *$ & 0,260 & & 0,229 & \\
\hline & $(2,03)$ & & $(2,26)$ & & $(0,74)$ & & $(\mathbf{0 , 7 1})$ & \\
\hline Log likelihood & 283,36 & & 280,72 & & & & & \\
\hline Wald chi square & 91,73 & $* * *$ & 94,41 & $* * *$ & & & & \\
\hline $\mathrm{R}^{2}$ & & & & & 0,21 & & 0,19 & \\
\hline F-Test & & & & & 2,38 & $* *$ & 3,08 & $* * *$ \\
\hline
\end{tabular}

Note: $* * * * *$, and $*$ denote significant $1 \%, 5 \%$, and $10 \%$ respectively

Null hypothesis is all coefficients are same in Wald coefficient \& F- Test. 
Table 13: The Result of regression Bank loans to LEs to other independent variables

This table reports Panel GLS and Clustering Fixed Effect model's estimation to bank loans to LEs. These panel data analysis methods use as major variables such as $\Delta \mathrm{GDP}_{\mathrm{t}-1}, \Delta \mathrm{GDP}_{\mathrm{t}}, \Delta \mathrm{Loan}{ }_{\mathrm{LEs}, \mathrm{t}, \mathrm{i}}$, and $\mathrm{CIV}_{\mathrm{LEs}, \mathrm{t}}$, (CIV factors are derived from cointegration analysis among cross-sectional data of bank and GDP variable) including interaction terms like $\Delta \mathrm{GDP}_{\mathrm{t}-1} \times \mathrm{BIS}_{\mathrm{t}-1, \mathrm{i}}$ $, \Delta \mathrm{GDP}_{\mathrm{t}-1} \times \mathrm{NPL}_{\mathrm{t}-1, \mathrm{i}}, \Delta \mathrm{GDP}_{\mathrm{t}-1} \times \mathrm{NIM}_{\mathrm{t}-1, \mathrm{i}}, \Delta \mathrm{GDP}_{\mathrm{t}-1} \times \mathrm{BO}(\text { Bank Ownership) })_{1}, \Delta \mathrm{GDP}_{\mathrm{t}-1} \times \mathrm{BO}(\text { Bank Ownership) })_{2}, \Delta \mathrm{GDP}_{\mathrm{t}-1}$ $\times \ln \operatorname{size}_{\mathrm{t}-1, \mathrm{i}}$

\begin{tabular}{|c|c|c|c|c|c|c|c|c|}
\hline \multirow[b]{3}{*}{ Constant } & \multicolumn{4}{|c|}{ Panel GLS Model } & \multicolumn{4}{|c|}{$\begin{array}{c}\text { Clustering Fixed Effect Model } \\
\text { (Clustering: Firm, Year) }\end{array}$} \\
\hline & \multicolumn{2}{|c|}{ Model 1} & \multicolumn{2}{|c|}{ Model 2} & \multicolumn{2}{|c|}{ Model 3} & \multicolumn{2}{|c|}{ Model 4} \\
\hline & $\mathbf{0 , 0 3 1}$ & $* * *$ & 0,029 & & 0,083 & $* * *$ & 0,081 & $* * *$ \\
\hline & $(2,73)$ & & $(\mathbf{0 , 8 5})$ & & $(5,70)$ & & $(5,67)$ & \\
\hline \multirow[t]{2}{*}{$\Delta \mathrm{GDP}_{\mathrm{t}-1}$} & $-1,983$ & & $-13,85$ & & $-9,721$ & & $-12,329$ & \\
\hline & $(-0,37)$ & & $(-1,24)$ & & $(-0,73)$ & & $(-0,97)$ & \\
\hline \multirow[t]{2}{*}{$\Delta \mathrm{GDP}_{\mathrm{t}}$} & 0,026 & & 0,122 & & $\mathbf{0 , 2 0 8}$ & & 0,210 & \\
\hline & $(0,15)$ & & $(0,52)$ & & $(0,74)$ & & $(0,79)$ & \\
\hline \multirow{2}{*}{$\Delta$ Loan $_{\mathrm{LEs}, \mathrm{t}-\mathrm{l}, \mathrm{i}}$} & 0,120 & & $-0,353$ & $* * *$ & $-0,344$ & $* * *$ & $-0,351$ & $* * *$ \\
\hline & $(1,25)$ & & $(-3,35)$ & & $(-2,70)$ & & $(-2,89)$ & \\
\hline \multirow{2}{*}{$\mathrm{CIV} . \mathrm{LEs}, \mathrm{t}$} & $-0,021$ & & $-0,028$ & & $-0,015$ & & $-0,021$ & \\
\hline & $(-0,97)$ & & $(-1,56)$ & & $(-0,55)$ & & $(-1,01)$ & \\
\hline \multirow{2}{*}{$\Delta \mathrm{GDP}_{\mathrm{t}-1} \times \mathrm{BIS}_{\mathrm{t}-1, \mathrm{i}}$} & $-0,031$ & & & & $-0,075$ & & & \\
\hline & $(-0,52)$ & & & & $(-0,69)$ & & & \\
\hline \multirow[t]{2}{*}{$\Delta \mathrm{GDP}_{\mathrm{t}-1} \times \mathrm{NPL}_{\mathrm{t}-1, \mathrm{i}}$} & 0,254 & & & & 0,328 & & & \\
\hline & $(\mathbf{0 , 7 0 )}$ & & & & $(0,62)$ & & & \\
\hline \multirow[t]{2}{*}{$\Delta \mathrm{GDP}_{\mathrm{t}-1} \times \mathrm{NIM}_{\mathrm{t}-1, \mathrm{i}}$} & $-0,218$ & & & & $-0,242$ & & & \\
\hline & $(-0,81)$ & & & & $(-0,69)$ & & & \\
\hline \multirow[t]{2}{*}{$\Delta \mathrm{GDP}_{\mathrm{t}-1} \times \mathrm{BO}_{1}$} & 0,245 & & $-\mathbf{0 , 0 3 0}$ & & $\mathbf{0 , 1 3 4}$ & & 0,011 & \\
\hline & $(1,15)$ & & $(-0,14)$ & & $(0,41)$ & & $(\mathbf{0 , 0 5})$ & \\
\hline \multirow[t]{2}{*}{$\Delta \mathrm{GDP}_{\mathrm{t}-1} \times \mathrm{BO}_{2}$} & $-0,309$ & & $-0,602$ & * & $-0,551$ & & $-0,564$ & \\
\hline & $(-1,64)$ & & $(-1,77)$ & & $(-1,34)$ & & $(-1,45)$ & \\
\hline \multirow[t]{2}{*}{$\Delta \mathrm{GDP}_{\mathrm{t}-1} \times \ln \operatorname{size}_{\mathrm{t}-1, \mathrm{i}}$} & 0,152 & & 0,782 & & 0,614 & & 0,698 & \\
\hline & $(\mathbf{0 , 5 0 )}$ & & $(1,28)$ & & $(\mathbf{0 , 8 3})$ & & $(1,00)$ & \\
\hline Log likelihood & 129,57 & & 69,00 & & & & & \\
\hline Wald chi square & 16,96 & $*$ & 56,55 & $* * *$ & & & & \\
\hline $\mathrm{R}^{2}$ & & & & & 0,32 & & $\mathbf{0 , 3 0}$ & \\
\hline F-Test & & & & & 4,20 & $* * *$ & 5,75 & $* * *$ \\
\hline
\end{tabular}

Note: $* * *, *$, and $*$ denote significant $1 \%, 5 \%$, and $10 \%$ respectively
Null hypothesis is all coefficients are same in Wald coefficient \& F- Test

Next let us review the $\triangle$ GDP variables in Table 13 . The estimated coefficients are negative to lagged $\triangle$ GDP, but are not significant in all models. Furthermore, the relationship among the first differential variables of GDP and dependent variables and the first differential bank loans to LEs is positive but insignificant regardless of models or estimation method. This suggests that the motivation for enhancing the relationship by banks is weak in the case of loans to LEs compared to SMEs.

\section{$\Delta$ Loan variables}

Considering the motivation of banks to enhance their relationship with SMEs, as mentioned above, we expect that a positive relationship between $\Delta$ Loan and lagged $\Delta$ Loan to SMEs. It is assumed that the motivation of banks to enhance their relationship with SMEs tends to skew financing policy towards continuity. As discussed in the analysis of the rolling VECM, all the coefficients of the lagged $\triangle$ Loan to SMEs shown in Table 12 have positive values with strong significance. Regardless of the model, information from former $\triangle$ Loans to SMEs may provide us with lending behavior. These results are consistent with those in Table 10 , which shows $\beta_{2}$ with significant and positive signs.

However, we cannot find any evidence to suggest that banks motivated to enhance relationships with LEs tend to skew financing policy towards continuity. Table 13 shows that the coefficients in all models except model 1, have negative signs with a significance of $1 \%$. The estimated coefficients are $0.120,-0.353,-0.344$, and -0.351 respectively. Estimated by using panel GLS, 0.120 is insignificant despite positive signs. These results are consistent with those in Table 11, which show $\beta_{2}$ with negative signs in all window periods. 
This result suggests that the financing policy of banks tends to be relationship-oriented towards SMEs for shortterm periods irrespective of the business cycle.

\section{The interaction terms}

This study incorporates interaction terms $\left(\Delta \mathrm{GDP}{ }_{\mathrm{t}-1} \times \mathrm{BIS}_{\mathrm{t}-}\right.$ ${ }_{1, \mathrm{i}}, \Delta \mathrm{GDP}_{\mathrm{t}-1} \times \mathrm{NPL}_{\mathrm{t}-1, \mathrm{i}}, \Delta \mathrm{GDP}_{\mathrm{t}-1} \times \mathrm{NIM}_{\mathrm{t}-1, \mathrm{i}}, \Delta \mathrm{GDP}_{\mathrm{t}-1} \times$ $\mathrm{BO}_{1}, \Delta \mathrm{GDP}_{\mathrm{t}-1} \times \mathrm{BO}_{2}$, and $\Delta \mathrm{GDP}{ }_{\mathrm{t}-1} \times \ln$ size $\left.\mathrm{t}-1, \mathrm{i}\right)$ in the panel data analysis to investigate the interaction effects of GDP and capital adequacy, loan soundness, profitability, governance structure, and the asset size of banks. First, in the case of capital adequacy, soundness, and profitability, the purpose of the analysis is to determine whether or not the interaction of banks with solid managerial conditions affects changes in loan policies at the current time. Second, it investigates assumptions related to governance structures, such as the idea that state-owned banks may stabilize credit, whereas, compared to domestic banks, foreign banks with low funding costs tend to concentrate on enhancing their relationship with SMEs. Third, it investigates whether or not bank size is correlated with lending behavior given that SMEs carry more business risk than LEs.

Table 12 and Table 13 shows that the estimated coefficients of $\Delta \mathrm{GDP}_{\mathrm{t}-1} \times \mathrm{BIS}_{\mathrm{t}-1, \mathrm{i}}$ are negative in the panel GLS and the clustering Fixed Effect model. The negative sign means that banks with a high BIS ratio increase current loans to SMEs or LEs despite economic recession because the sign of $\Delta \mathrm{GDP}_{\mathrm{t}-1}$ to current $\Delta$ loan is definitely negative. This result is consistent with Jokipii and Milne (2008) who demonstrated that the capital buffers of 15 EU banks have negative co-movement with the business cycle.

However, the relationship between capital adequacy and lending behavior is not unique to bank loans to SMEs. Furthermore, because of statistical insignificance it is not strongly confirmed that capital adequacy is a definite determinant in decisions to lend to enterprises.

The estimated coefficients of $\Delta \mathrm{GDP}_{\mathrm{t}-1} \times \mathrm{NPL}_{\mathrm{t}-1, \mathrm{i}}$ shown in Table 12 and Table 13 have positive signs but are insignificant. It can be cautiously suggested that under economic recession, banks with a low NPL ratio may increase loans to SMEs or LEs in the next time frame. Based on previous studies, it is understood that interested parties may cause banks with high NPL ratios to reduce their issuance of risky loans. Specifically, government supervisors or regulators, depositors and other capital market investors, and risk-averse managers in banks may encourage or require distressed banks to reduce the number of these loans. In their study of the banking sectors in Argentina, Chile, and Mexico, Martinez, Peria and Schmukler (2001) asserted that depositors disciplined risky banks by withdrawing their deposits. Although the relationship between the business cycle and NPL is positive in this analysis of panel data, because of its statistical insignificance, it deemed that the NPL ratio is not a critical determinant for lending behavior.

On the other hand, the estimated coefficients of $\Delta \mathrm{GDP}_{\mathrm{t}-1} \times$ NIM $_{t-1, i}$ shown in Table 8 are negative in all models. In particular, the sign of model 1 using panel GLS to include all managerial conditions of banks shows a significance of $1 \%$. In other words, banks with advantages in generating profits increase loans to SMEs, the margin of which is generally bigger despite economic recession.

In the light of this evidence, this result supports the above explanation that banks tend to increase risky loans to SMEs to reap future benefits. Unfortunately, this statistical significance with a negative sign does not appear in model 3 , as shown in Table 12. Neither did the results indicate that NIM might explicitly affect lending behavior to LEs, as shown in Table 13, because all coefficients are insignificant although they all have negative signs.

Like most of the existing literature on governance structure such as role of state-owned banks and so called credit stabilization, this study tests whether state ownership of banks is related to lending behavior over the business cycle.

Table 12 shows that the estimated coefficients of $\Delta \mathrm{GDP}_{\mathrm{t}-1} \times$ $\mathrm{BO}_{1}$ (banking ownership 1: dummy variable 1 or -1 if it is a private bank or a state-owned bank) are consistently negative particularly if they are significant at $5 \%$ and $1 \%$, respectively, in model 1 and model 2 using panel GLS. However, they are insignificant in the clustering fixed effect model. It is understood that private banks more positively increase SMEs loan than do state-owned banks in economic recession. This result is inconsistent with that of Micco and Panizza (2006) who insisted that state-ownership of banks is correlated with lending behavior over the business cycle. They found that the lending of these banks is less responsive to macroeconomic shocks than is the lending of private banks. Actually, as private banks, Korean commercial banks are eager to increase SMEs loans completely because of the maturation of other lending businesses such as household loans and LEs loans.

Table 13 shows that estimated coefficients are generally positive and insignificant. This result confirms that private banks do not attract lending businesses, such as the abovementioned LEs loans.

In addition to reviewing governance structure, such as the credit stabilization of state-owned banks, it is assumed that foreign-owned banks are less likely to lend to small companies that have opaque information than they are to lend to domestically owned banks (Berger, Klapper \& Undell, 2001). Hence, the interaction term, $\Delta$ GDP ${ }_{\mathrm{t}-1} \times \mathrm{BO}_{2}$ (banking ownership 2: dummy variable 1 or -1 if it is a domestically owned bank or foreign-owned bank), should be checked, as shown in Table 12. This result shows that domestically owned-banks increase SMEs loans more positively than do foreign-owned banks over economic recession because the estimated signs are all negative. Using Panel GLS, the signs are statistically significant at $1 \%$. However, clustering fixed effect model shows no significance. The evidence that the signs are all negative regardless of estimation method, partly showing strong significance in the estimation results, is the similar to the prediction.

Similar results of the analysis of LEs loans are shown in Table 13 even though the statistical significance is very 
weak. The estimated signs are all negative, which means that domestically owned-banks tend to increase LEs more than do foreign-owned banks over economic recession. Model 2 in Table 13 shows a significance of only $10 \%$. Therefore, domestically owned banks tend to increase loans regardless of whether they lend to SMEs or LEs despite economic recession. As the previous literature observed, it is presumed that domestically owned banks gather information on companies at expense and are likely to information on locally based relationships.

There is another assumption related to banking hypotheses - the large-bank barriers hypothesis that large banks tend to have difficulty in extending relationship loans to SMEs (Berger et al., 2001). This hypothesis is based on the assumption that large banks generally hold that it is too costly to provide relationship services to small businesses in addition to their services to large corporate customers. Table 12 shows evidence in line with the large-bank barriers hypothesis as far as the result of panel GLS is concerned, in which the coefficients are all positive, indicating that smaller a bank's assets are, the larger the increase in bank loans to SMEs despite depression $\mathrm{n}$ the business cycle. This means that smaller bank loans to SMEs are less responsive to economic shock than are bigger bank loans. In other words, bigger bank loans to SMEs tend to have comparative procyclicality.

In the case of analysis of LE loans shown in Table 13, there is no evidence on large-bank barriers. All estimated coefficients have no significance.

To confirm the robustness of these coefficients in panel GLS and the clustering Fixed Effect model, they were tested by the Wald coefficient and F-test. All results strongly rejected null hypotheses, indicating that all the coefficients estimated are the same.

\section{Conclusion}

This study primarily examines the relationship between the first differentials of bank loans and business cycles to confirm whether procyclicality exists in bank loans to SMEs and LEs. In addition, it reviews the dynamics among first differential variables such as $\Delta \mathrm{GDP}, \Delta$ bank loans, and other bank characteristics based on hypotheses related to governance structures, large-bank barriers, and so on. Much of the empirical literature in this field has focused on examining the determinants of bank loans or the relation with business cycle using panel data analysis. This study takes the unique approach of evaluating previous hypotheses by using the analysis of both aggregated and panel data.

The study's findings are summarized below. First, it was found that for the period from 1999 to 2008, procyclicality existed in bank loans to SMEs, but not in those made to LEs. This finding suggests that a positive relationship exists between changes in lending behavior to SMEs and the business cycle. The rolling VECM and panel data analysis found that the business cycle does play a pivotal role in determining lending behavior to SMEs.

Second, the motivation of banks to enhance relationships with enterprises is especially strong in the case of loans to
SMEs. The results of the dynamics among first differential variables such as lagged $\triangle G D P$ and $\Delta$ Loans support Dell'Ariccia and Marquez (2001) who referred to future benefits as being "captured." The negative relationship between $\Delta \mathrm{GDP}_{\mathrm{t}-1}$ and $\Delta$ Loans $\mathrm{t}_{\mathrm{t}}$ is attributed to the fact that the banks' motivation for making a profit despite economic recession increases bank loans to SMEs for short-term periods. This motivation is attributed to the banks' need for more profitability rather than the interested parties' demand for soundness or capital adequacy.

Third, regarding the governance structure hypotheses, private banks in Korea tend to be more eager than stateowned banks to increase loans during a recession, which is the opposite of the expected lending behavior according to Micco and Panizza (2006). It is possible that the opposite result is attributable to the competitive nature of the banking industry in Korea. In addition, domestically owned-banks concentrate more on SMEs financing than do foreign-owned banks, despite economic recession. This finding supports the conclusions of Berger et al. (2001).

Finally, it is suggested here that the loans of smaller banks to SMEs tend to be less responsive to economic shock, which is in line with the large-bank barriers hypothesis.

This study concludes that changes in bank loans to SMEs are vulnerable to external economic conditions, whereas privately held commercial banks continue to enhance their SMEs financing business in order to make short-term profits. According to this finding, the conventional role of the relationship of Korean state-owned banks to SMEs, that is, credit stabilization, needs to be strengthened to prepare for a long economic slump.

\section{Acknowledgement}

This paper was financially supported by Sangmyung University in the year of 2013.

\section{References}

Aggarwal, R. \& Jacques, K.T. 2001. 'The impact of FDICIA and prompt corrective action on bank capital and risk: Estimates using a simultaneous equations model', Journal of Banking and Finance, 25: 1139-1160.

Albertazzi, U. \& Gambacorta, L. 2009. 'Bank profitability and the business cycle', Journal of Financial Stability, 5: 393-409.

Ayuso, J., Perez, D. \& Saurina, J. 2004. 'Are capital buffers pro-cyclical? Evidence from Spanish panel data', Journal of Financial Intermediation, 13: 249-264.

Baltagi, H.B. 1996. Econometric analysis of panel data. West Sussex, England: John Wiley \& Sons LTD.

Barth, J., Caprio, G. \& Levine, R. 2006. Rethinking bank supervision and regulation: Till angels govern. Cambridge: Cambridge University Press. 
Beatty, A. \& Liao, S. 2011. 'Do delays in expected loss recognition affect banks' willingness to lend?' Journal of Accounting and Economics, 52: 1-20.

Benford, B. \& Nier, E. 2007. 'Monitoring cyclicality of Basel II capital requirements', Financial Stability Paper 3.

Berger, A.N. \& Udell, G.F. 1994. 'Did risk-based capital allocate bank credit and cause a 'credit crunch' in the United States?' Journal of Money, Credit, and Banking, 26: 585628.

Berger, A.N., Clarke, G.R.G., Cull, R., Klapper, L. \& Udell, G.F. 2005. 'Corporate governance and bank performance: A joint analysis of the static, selection, and dynamic effects of domestic, foreign, and state ownership', Journal of Banking \& Finance, 29: 2179-2221.

Berger, A.N., Klapper, L.F. \& Udell, G.F. 2001. 'The ability of banks to lend to informationally opaque small businesses', Journal of Banking and Finance, 25: 21272167.

Bernanke, B.S. \& Blinder, A.S. 1988. Credit, money, and aggregate demand', American Economic Review, 78: 435439.

Chiou, I. 1999. Daiwa Bank's reputational crisis: Valuation effects on bank-firm relationships. Working Paper, New York University.

Claessens, S., Djankov, S. \& Ferri, G. 1999. Corporate distress in East Asia : The effect of currency and interest rate shocks. Working Paper, World Bank.

Dell' Ariccia, G. \& Marquez, R. 2001. Flight to quality or to captivity? Information and credit allocation. IMF Working Paper, pp.1-25.

Djankov, S., Jindra, J. \& Klapper, L. 2000. Corporate valuation and the resolution of bank insolvency in East Asia. Working Paper, World Bank.

Estrella, A. 2004. 'The cyclical behaviour of optimal bank capital', Journal of Banking and Finance, 28: 1469-1498.

Francis, W. \& Osborne, M. 2009. Bank regulation, capital and credit supply: measuring the impact of Prudential Standards. UK Financial Services Authority Occasional Paper Series, No 36.

Gambacorta, L. \& Mistrulli, P.E. 2004. 'Does bank capital affect lending behavior?' Journal of Financial Intermediation, 13: 436-457.

Grosse, R. \& Goldberg, L.G. 1991. 'Foreign bank activity in the United States: An analysis by country of origin', Journal of Banking and Finance, 15: 1093-1112.

Guirguis, H., Giannikos, C. \& Anderson, R. 2005. 'The US Housing Market: Asset pricing forecasts using time varying coefficients' The Journal of Real Estate Finance and Economics, 30: 33-53.
Hancock, D., Laing, A. \& Wilcox, J. 1995. 'Bank balance sheet shocks and aggregate shocks: Their dynamics effects on bank capital and lending', Journal of Banking and Finance, 19: 661-677.

Jokipii, T. \& Milne, A. 2008. 'The cyclical behavior of European bank capital buffers', Journal of Banking and Finance, 32: 1440-1451.

Kang, J.K. \& Stulz, R.M. 2001. 'Do banking shocks affect borrowing firm performance? An analysis of the Japanese experience', Journal of Business, 73: 1-23.

Kashyap, A. K. \& Stein, J.C. 2000. 'What do a million observations on banks say about the transmission of monetary policy?' American Economic Review, 90: 407428.

Kashyap, A.K. \& Stein, J.C. 2004. 'Cyclical implications of the Basel II standards, economic perspectives', Federal Reserve Bank of Chicago, Quarter 1: 18-31.

Kishan, Ruby P. \& Opiela, T.P. 2006. 'Bank capital and loan asymmetry in the transmission of monetary policy', Journal of Banking and Finance, 30: 259-285.

Laeven, L. \& Majnoni, G. 2003. 'Loan loss provisioning and economic slowdowns: Too much, too late?' Journal of Financial Intermediation, 12: 178-197.

Lindquist, K.G. 2004. 'Banks buffer capital: How important is risk?' Journal of International Money and Finance, 23: 493-513.

Martinez Peria, M. S. \& Schmukler, S. 2001. 'Do depositors punish banks for bad behavior? Market discipline, deposit insurance and banking crises', Journal of Finance, 56: 1029-1051.

Micco, A. \& Panizza, U. 2006. 'Bank ownership and lending behavior', Economics Letters, 93: 248-254.

Milne, A. \& Whalley, E. 2001. Bank capital regulation and incentives for risk-taking. Working Paper, SSRN.

Nier, E. \& Zicchino, L. 2005. 'Bank weakness and bank loan supply’, Financial Stability Review, 19: 85-93.

Ongena, S., Smith, D. \& Michalsen, D. 2000. Firms and their distressed banks: Lessons from the Norwegian Banking Crisis (1988-1991). Federal Reserve Board Working Paper.

Peek, J. \& Rosengren, E.S. 1995. 'The capital crunch: neither a borrower nor a lender be', Journal of Money, Credit and Banking, 27: 625-638.

Salas, V. \& Saurina, J. 2002. 'Credit risk in two institutional settings: Spanish commercial and saving banks', Journal of Financial Services Research, 22: 203-224.

Saurina, J. \& Truncharte, C. 2006. 'An assessment of Basel II procyclicality in mortgage portfolios'. $6^{\text {th }}$ Annual Bank Research Conference, The FDIC Virginia Square Facility, 
3501 North Fairfax Drive, C-3050, Arlington, Virginia 22226, U.S.

Shrieves, R.E. \& Dahl, D. 1995. 'Regulation, recession, and bank lending behavior: The 1990 credit crunch', Journal of Financial Services Research, 9: 5-30.

Stolz, S. \& Wedow, M. 2011. 'Banks' regulatory capital buffer and the business cycle: Evidence for Germany', Journal of Financial Stability, 7: 98-110.

Wagster, J.D. 1999. 'The Basel Accord of 1988 and the international credit crunch of 1989-1992', Journal of Financial Services Research, 15: 123-143. 